\title{
The secret life of kinases: functions beyond catalysis
}

Jens Rauch ${ }^{1 *}$, Natalia Volinsky ${ }^{1}$, David Romano ${ }^{1}$ and Walter Kolch ${ }^{1,2^{*}}$

\begin{abstract}
Protein phosphorylation participates in the regulation of all fundamental biological processes, and protein kinases have been intensively studied. However, while the focus was on catalytic activities, accumulating evidence suggests that non-catalytic properties of protein kinases are essential, and in some cases even sufficient for their functions. These non-catalytic functions include the scaffolding of protein complexes, the competition for protein interactions, allosteric effects on other enzymes, subcellular targeting, and DNA binding. This rich repertoire often is used to coordinate phosphorylation events and enhance the specificity of substrate phosphorylation, but also can adopt functions that do not rely on kinase activity. Here, we discuss such kinase independent functions of protein and lipid kinases focussing on kinases that play a role in the regulation of cell proliferation, differentiation, apoptosis, and motility.
\end{abstract}

Keywords: kinase, kinase-independent, non-catalytic, ERBB, EGFR, Raf, ERK, Src, PI3K, AKT, IGF, Cell cycle, PAK, PDK, FAK, ASK

\section{Introduction}

Kinases are conserved during evolution. Orthologs with 'kinase domains' (so-called protein kinase-like folds; PKL) are found in all three domains of life, [1]. Interestingly, comparing the 'kinomes' from nematodes, insects, and vertebrates a surprising number of kinases are shared. In eukaryotes, the protein kinase family is one of the largest gene families, counting for about $2 \%$ of all genes. The human genome contains 518 putative protein and lipid kinases. Based on sequence similarities they can be divided into 9 groups of conventional kinases, which feature a typical kinase domain sequence, and 8 small groups of unconventional kinases, which lack typical kinase domain sequences but reportedly possess biochemical kinase activity $[2,3]$. Almost half of the human kinases can be mapped to known disease loci, cancer amplicons, and mutations or their deregulation can be directly correlated to human disease. Therefore, it comes as no surprise that kinases are intensively studied, and kinase inhibitors have now a firm place in the pharmaceutical armoury.

The importance of protein phosphorylation is underlined by a Nobel Prize in Physiology or Medicine awarded

\footnotetext{
* Correspondence: jens.rauch@ucd.ie; walter.kolch@ucd.ie

'Systems Biology Ireland, University College Dublin, Belfield, Dublin 4, Ireland
} Full list of author information is available at the end of the article to Edmond H. Fischer and Edwin G. Krebs in 1992 "for their discoveries concerning reversible protein phosphorylation as a biological regulatory mechanism". Their key discovery about 55 years ago was that the conversion of the inactive enzyme phosphorylase $b$ to the active phosphorylase a is caused by phosphorylation, and that the conversion factor is a protein kinase, phosphorylase kinase $[4,5]$. That breakthrough has established a firm role for protein kinases in the regulation of diverse fundamental cellular processes and spawned an immensely fruitful field of kinase research. At the same time this success, however, has blinkered us to solely concentrate on the catalytic activities of kinases neglecting other functions of these proteins, which do not require the phosphotransferase activity.

Early examples of non-catalytic functions of protein kinases were discovered in yeast. In 1997 Posas and Saito showed that the yeast $\mathrm{Pbs} 2 \mathrm{p}$ protein can serve both as a scaffolding protein and a protein kinase [6]. The adaptation of the yeast $S$. cerevisiae to high osmolarity is regulated by two independent pathways, which both contain a three-tiered cascade of kinases. In one of these pathways Pbs2p serves as a bona fide kinase (MAPKK), which links signalling from SSK2/SSK22 (a MAPKKK) to HOG1 (a MAPK). In the other pathway
C Biomed Central 
Pbs2p functions both as a kinase and a scaffold by assembling a complex of Sholp, Ste11p, and Hog1p proteins and at the same time providing the kinase link between Ste11p and Hog1p (Figure 1A). In another example from budding yeast, Madhani and colleagues showed in 1997 that the MAPK Kss1 has important non-catalytic functions [7]. Non-phosphorylated Kss1 inhibits filamentation and haploid invasion through the kinase independent inhibition of the Ste12-Tec1 transcription factor complex. Phosphorylation by Ste7 (a MAPKK) activates Kss1 catalytic activity and converts Kss1 from a repressor of filamentation into an activator. This second function of Kss1 requires its kinase activity, which acts to stimulate the Ste12-Tec1 complex (Figure 1B).

Although these discoveries are not only early but still some of the clearest examples for a dual function of protein kinases, this new conceptual view did not gain traction until the last few years where a flurry of other examples began to emerge and are now receiving sharply increasing attention.

This review presents a synopsis of protein kinase functions that are independent of catalytic activity, with a special focus on kinases involved in the regulation of proliferation, apoptosis, differentiation, cell adhesion and migration. A comprehensive summary is given in Table 1. Due to space constraints we do not discuss the functions of pseudokinases, but only review recent results suggesting that in some cases their catalytic activities have developed to become highly specialized rather than being lost.

\section{Receptor Tyrosine Kinases (RTK)}

Receptor Tyrosine Kinases (RTK) comprise a family of about 60 cell surface receptors, which act as docking platforms for polypeptide-based growth factors, cytokines, and hormones [8]. RTKs are starting points for several signalling pathways, and hence are not only key regulators of many normal cellular processes, but also play a major role in development and progression of many malignancies [9]. Among the 60 receptors of the RTK family, several family members are involved in mechanisms where no kinase activity is required.

\section{The Epidermal Growth Factor Receptor (EGFR/ERBB1) ERBB family}

The ERBB family of RTKs is one of the best known and most extensively studied signal transduction networks with implications ranging from cell division to cell death and motility to cellular adhesion (extensively reviewed in $[10,11])$. The receptor family consists of 4 members: ERBB1 (also known as HER1 or EGFR), ERBB2 (also known as HER2/neu), ERBB3 (HER3), and ERBB4 (HER4), which can form homo- and heterodimers with specific functions. 11 specific ligands are known to bind and activate ERBB receptors, which are the starting points of downstream signalling pathways such as MAPK, AKT and JNK signalling cascades [12].

The EGFR is activated by binding of several ligands, including epidermal growth factor (EGF) and transforming growth factor alpha (TGF $\alpha$ ). EGFR forms homodimers as well as three functional heterodimers with the other members of the ERBB family, which stimulates its intrinsic intracellular protein-tyrosine kinase activity and results in autophosphorylation of several tyrosine residues in the Cterminal domain of EGFR [13]. These phospho-tyrosines serve as docking sites for an array of signal transducers [14], including kinases, phosphatases, transcription factors, and several adaptor proteins such as GRB2 and Shc, which are responsible for the initiation of multiple downstream signalling pathways. With this functional repertoire, it comes as no surprise, that deregulation of expression levels, gene amplifications and mutations of the EGFR or
A) Dual function of Pbs2 as scaffold and kinase

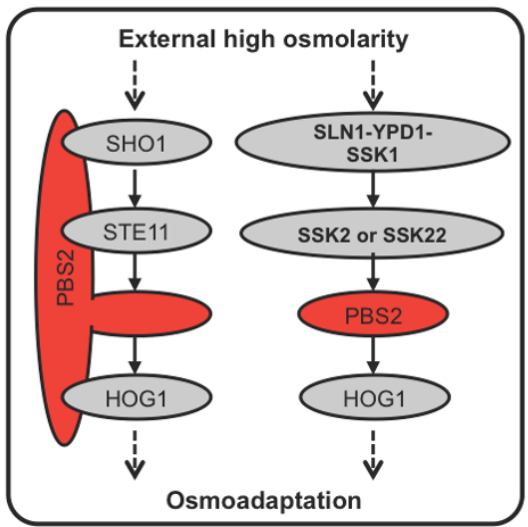

B) Antagonistic functions of Kss1

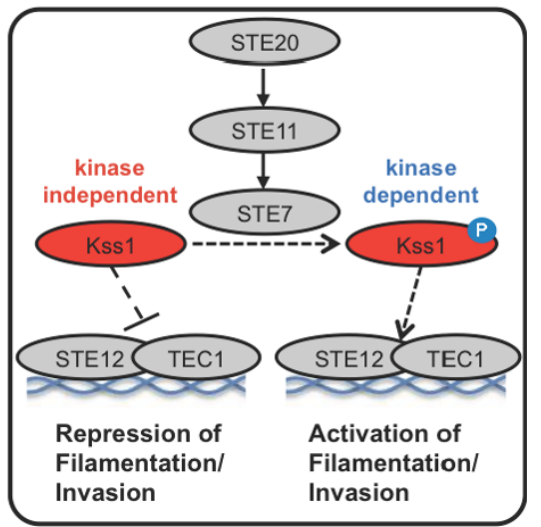

Figure 1 Examples of catalytic-independent functions in yeast. (A) The dual role of PBS2 as scaffold and kinase in yeast osmo-sensing pathways. (B) Antagonistic functions of the kinase Kss1 in filamentation and invasion. 
Table 1 Catalytic-independent kinase functions according to the $\mathbf{7}$ major kinase groups

\begin{tabular}{|c|c|c|c|c|}
\hline $\begin{array}{l}\text { Kinase } \\
\text { Group }\end{array}$ & Protein & Notes & Organism & References \\
\hline \multirow{22}{*}{$\begin{array}{l}\text { Receptor } \\
\text { Tyrosine } \\
\text { Kinases } \\
\end{array}$} & EGFR & $\begin{array}{l}\text { Mitogen-activated protein kinase stimulation by a tyrosine kinase- } \\
\text { negative epidermal growth factor receptor }\end{array}$ & $\begin{array}{l}\mathrm{CHO} \text { (Chinese hamster } \\
\text { ovary) cells }\end{array}$ & [21] \\
\hline & & $\begin{array}{l}\text { Tyrosine phosphorylation of mitogen-activated protein kinase in cells } \\
\text { with tyrosine kinase-negative epidermal growth factor receptors }\end{array}$ & B82L cells (mouse) & [19] \\
\hline & & $\begin{array}{l}\text { EGFR-ERBB2 oligomers activate ERK and Akt, independent of EGFR } \\
\text { kinase activity }\end{array}$ & human & [24] \\
\hline & & Kinase-negative EGFR retains the capacity to stimulate DNA synthesis & $\begin{array}{l}\text { CHO cell line } \\
\text { (hamster) }\end{array}$ & {$[20]$} \\
\hline & & No kinase activity of EGFR is required for activation of $\mathrm{c}$-fos expression & mouse & [23] \\
\hline & & $\begin{array}{l}\text { Kinase-independent EGFR prevents autophagic cell death by } \\
\text { maintaining intracellular glucose level through interaction and } \\
\text { stabilization of the sodium/glucose cotransporter } 1 \text { (SGLT1). }\end{array}$ & human & [16] \\
\hline & & $\begin{array}{l}\text { EGFR and EGFRvIII interact with PUMA to inhibit mitochondrial } \\
\text { translocalization of PUMA and PUMA-mediated apoptosis independent } \\
\text { of EGFR kinase activity. This function of EGFR/EGFRvlll leads to tumor } \\
\text { drug resistance of glioblastoma. }\end{array}$ & human & [25] \\
\hline & ApTrkl & $\begin{array}{l}\text { Aplysia Trk-like receptor (ApTrkl), a Trk-like receptor in Aplysia sensory } \\
\text { neurons, was shown to have two modes of receptor internalization: } \\
\text { kinase activity-dependent internalization and serotonin-dependent, } \\
\text { kinase activity-independent internalization }\end{array}$ & mouse & [213] \\
\hline & Insulin Receptor & $\begin{array}{l}\text { Unliganded insulin- and IGF-1 receptors exert a permissive effect on } \\
\text { cell death }\end{array}$ & Mouse adipocytes & [214] \\
\hline & & $\begin{array}{l}\text { Induces phosphorylation and activation of phosphatase PHLPP1, a } \\
\text { negative regulator of Akt2 activity }\end{array}$ & & [215] \\
\hline & $\begin{array}{l}\text { Insulin-Like Growth } \\
\text { Factor I (IGF-1) } \\
\text { Receptor }\end{array}$ & $\begin{array}{l}\text { Mediates Erk } 1 / 2 \text { phosphorylation in a tyrosine phosphorylation } \\
\text { independent manner. }\end{array}$ & Smooth muscle cells & [34] \\
\hline & EphA2 & $\begin{array}{l}\text { Some of EphA2 functions in cell motility, invasion and bone formation } \\
\text { are kinase-independent }\end{array}$ & & {$[216]$} \\
\hline & EphA4/SEK1 & $\begin{array}{l}\text { Kinase-dependent and kinase-independent functions of EphA4 } \\
\text { receptors in major axon tract formation in vivo }\end{array}$ & mouse & {$[217]$} \\
\hline & EphA8 & Overexpression of EphA8 enhances cell attachment to fibronectin & & {$[218]$} \\
\hline & EphB/NUK & $\begin{array}{l}\text { Kinase independent function of EphB receptors in retinal axon path } \\
\text { finding to the optic disc from dorsal but not ventral retina }\end{array}$ & mouse & [219] \\
\hline & & $\begin{array}{l}\text { Kinase-Independent Requirement of EphB2 Receptors in Hippocampal } \\
\text { Synaptic Plasticity }\end{array}$ & mouse & {$[220]$} \\
\hline & & $\begin{array}{l}\text { EphB2 regulates positioning of differentiated Paneth cells in small } \\
\text { intestine independently of kinase activity }\end{array}$ & intestinal epithelium & [221] \\
\hline & EphB3 & $\begin{array}{l}\text { EphB3 is overexpressed in non-small-cell lung cancer and promotes } \\
\text { tumor metastasis in a kinase-independent manner. }\end{array}$ & Lung & {$[222]$} \\
\hline & & $\begin{array}{l}\text { Overexpression of wild type or kinase dead protein decreases Cdc42/ } \\
\text { Rac activity and reduces cell migration. }\end{array}$ & & [223] \\
\hline & EphA3 & $\begin{array}{l}\text { In the absence of ephrin interaction, kinase-dead EphA3 recruits other } \\
\text { Eph molecules for oligomerization }\end{array}$ & human & {$[224,225]$} \\
\hline & VAB-1 & $\begin{array}{l}\text { VAB-1, a C. elegans Eph receptor, regulates embryonic development } \\
\text { by kinase-dependent and -independent functions }\end{array}$ & C. elegans & {$[226-228]$} \\
\hline & c-kit & $\begin{array}{l}\text { Complex formation with granulocyte macrophage colony-stimulating } \\
\text { factor (GM-CSF) receptor. }\end{array}$ & & {$[229]$} \\
\hline \multirow[t]{2}{*}{$\begin{array}{l}\text { Non-receptor } \\
\text { Tyrosine } \\
\text { kinases }\end{array}$} & Src & $\begin{array}{l}\text { Overexpresion of non-catalytic domains of Src alters focal adhesion } \\
\text { properties }\end{array}$ & & [107] \\
\hline & & $\begin{array}{l}\text { c-Src enhances the spreading of src-/- fibroblasts on fibronectin by a } \\
\text { kinase-independent mechanism }\end{array}$ & mouse & [109] \\
\hline
\end{tabular}


Table 1 Catalytic-independent kinase functions according to the $\mathbf{7}$ major kinase groups (Continued)

\begin{tabular}{|c|c|c|c|c|}
\hline & & $\begin{array}{l}\text { Activation of the Src-dependent adaptor protein pp130cas in } \\
\text { fibroblasts in response to fibronectin binding does not require intrinsic } \\
\text { Src kinase activity }\end{array}$ & mouse & {$[110]$} \\
\hline & & Kinase-deficient Src protects src-/- mice against osteopetrosis. & mouse & {$[112]$} \\
\hline & & Src mediates B cell antigen Receptor response & & {$[230]$} \\
\hline & & $\begin{array}{l}\text { Src mediates FAK phosphorylation at several tyrosine residues } \\
\text { independently of its kinase activity }\end{array}$ & $\begin{array}{l}\mathrm{KM} 12 \mathrm{C} \text { (Human colon } \\
\text { cancer) }\end{array}$ & {$[111]$} \\
\hline & & $\begin{array}{l}\text { Src regulates Jak2/Stat5 activation induced by prolactin in mammary } \\
\text { tissue in a kinase-independent manner }\end{array}$ & & [113] \\
\hline & Brk & Brk (PTK6) promotes breast carcinoma cell proliferation & & {$[231]$} \\
\hline & FRK-1 & $\begin{array}{l}\text { Fer-related kinase-1 (FRK-1) performs a kinase-independent function in } \\
\text { differentiation and morphogenesis of the C. elegans epidermis during } \\
\text { embryogenesis. }\end{array}$ & $\begin{array}{l}\text { Caenorhabditis } \\
\text { elegans }\end{array}$ & {$[232]$} \\
\hline & Lck & $\begin{array}{l}\text { Kinase-independent function of Lck in potentiating antigen-specific T } \\
\text { cell activation }\end{array}$ & human & {$[114]$} \\
\hline & Hck & $\begin{array}{l}\text { The Src Family Kinase Hck Interacts with Bcr-Abl by a Kinase- } \\
\text { independent Mechanism and Phosphorylates the Grb2-binding Site of } \\
\text { Bcr-Abl }\end{array}$ & COS7 cells & [233] \\
\hline & Lyn & $\begin{array}{l}\text { Negative regulation of } B \text { cell } A g \text { receptor }(B C R) \text { induced activation of } \\
\text { Protein Kinase } C(P K C)\end{array}$ & Chicken B cells & {$[115$} \\
\hline & & $\begin{array}{l}\text { Lyn increases p53 levels and stimulates p53-mediated transcription by } \\
\text { a kinase-independent mechanism }\end{array}$ & & {$[234]$} \\
\hline & $c-A b l$ & Promotes p53 DNA binding & & {$[235$} \\
\hline & & $\begin{array}{l}\text { Negatively regulates UV damaged DNA repair by recruiting CAL- } 4 A \\
\text { ubiquitin ligase }\end{array}$ & & {$[236$} \\
\hline & & $\begin{array}{l}\text { c-Abl promotes proteolytic destruction of damaged DNA binding } \\
\text { proteins in a kinase-independent manner }\end{array}$ & mouse & {$[236$} \\
\hline & & $\begin{array}{l}\text { Abl proper subcellular localization is correlated with its kinase- } \\
\text { independent activity }\end{array}$ & Drosophila & {$[237]$} \\
\hline & $\begin{array}{l}\text { FAK (Protein } \\
\text { Tyrosine Kinase 2) }\end{array}$ & FAK initiates endothelial cell development during embryogenesis & $\begin{array}{l}\text { Mouse endothelial } \\
\text { cells }\end{array}$ & {$[124]$} \\
\hline & & FAK promotes cell survival by enhancing p53 degradation & $\begin{array}{l}\text { Mouse fibroblasts and } \\
\text { human cell lines }\end{array}$ & {$[126$} \\
\hline & & $\begin{array}{l}\text { Mediates JNK activation in a kinase-independent manner by recruiting } \\
\text { paxillin to the plasma membrane }\end{array}$ & & {$[118$} \\
\hline & $\begin{array}{l}\text { Pyk2 (Protein } \\
\text { Tyrosine Kinase 2 B) }\end{array}$ & Pyk2 facilitates cell growth and survival by limiting p53 levels & MEF and cell lines & {$[128]$} \\
\hline & ACK (TNK2) & $\begin{array}{l}\text { The scaffold function of ACK, rather than kinase activity, seems } \\
\text { important in the context of cell growth control }\end{array}$ & human & {$[238$} \\
\hline & ACK2 & $\begin{array}{l}\text { Overexpressed ACK2 inhibits kinase activity of FAK and cell growth } \\
\text { independently of its kinase activity; however its ability to dissolve actin } \\
\text { stress fibers and to disassemble focal complexes requires kinase } \\
\text { activity }\end{array}$ & $\mathrm{NIH} 3 \mathrm{~T} 3$ cell line & {$[239$} \\
\hline & $\mathrm{BMX}$ & $\begin{array}{l}\text { Bone Marrow Kinase (BMX) regulates inflammation in rheumatoid } \\
\text { arthritis }\end{array}$ & mouse & {$[240]$} \\
\hline & Itk & $\begin{array}{l}\text { Itk mediates antigen receptor induced activation of transcription factor } \\
\text { SRF (Serum Response Factor) independently of its kinase activity }\end{array}$ & DT40 chicken B cells & {$[241]$} \\
\hline & & $\begin{array}{l}\text { Itk regulates Vav localization and T cell Receptor-induced actin } \\
\text { polarization independently of its kinase activity. }\end{array}$ & T cells & {$[242]$} \\
\hline & Zap-70 & $\begin{array}{l}\text { Whereas the kinase activity of Zap- } 70 \text { is required for signal } \\
\text { transduction downstream to the } T \text { cell antigen receptor (TCR), this } \\
\text { protein has kinase-independent functions in activating small G protein } \\
\text { Rap1, required for integrin-mediated adhesion. }\end{array}$ & T cells & {$[243]$} \\
\hline TKL & $\mathrm{T} \beta \mathrm{RI}$ & TGF $\beta$ receptor recruits and activates TAK1 via interaction with TRAF6 & human & {$[244$} \\
\hline & Raf-1 & Raf- 1 binds to and inhibits ROK-alpha kinase activity & MEF & [66] \\
\hline & & $\begin{array}{l}\text { Raf-1 plays an essential, kinase-independent function as a spatial } \\
\text { regulator of Rho downstream signaling during migration. }\end{array}$ & MEF & [65] \\
\hline
\end{tabular}


Table 1 Catalytic-independent kinase functions according to the $\mathbf{7}$ major kinase groups (Continued)

\begin{tabular}{|c|c|c|c|c|}
\hline & & $\begin{array}{l}\text { Raf- } 1 \text { sets the threshold of Fas sensitivity by modulating ROK- } \alpha \\
\text { signaling }\end{array}$ & MEF & [64] \\
\hline & & $\begin{array}{l}\text { Raf-1:ROK-alpha complex linked to STAT3/Myc activation is crucial for } \\
\text { cell fate decisions in Ras-induced tumorigenesis. }\end{array}$ & mouse & [67] \\
\hline & & Raf-1 binds and inhibits the pro-apoptotic kinase MST2 & $\begin{array}{l}\text { human and mouse } \\
\text { cell lines }\end{array}$ & {$[68-70,245]$} \\
\hline & & Raf-1 binds and inhibits the pro-apoptotic kinase ASK1 & mouse & [246] \\
\hline & & $\begin{array}{l}\text { Cardiac-specific disruption of the Raf-1 gene induces cardiac } \\
\text { dysfunction and apoptosis }\end{array}$ & mouse & [75] \\
\hline & & $\begin{array}{l}\text { Raf-1 promotes cell survival by antagonizing apoptosis signal- } \\
\text { regulating kinase } 1 \text { through a MEK-ERK independent mechanism }\end{array}$ & human & [74] \\
\hline & & $\begin{array}{l}\text { MEK kinase activity of Raf-1 is not essential for function and normal } \\
\text { mouse development. Raf-1 plays a role in preventing apoptosis. }\end{array}$ & mouse & {$[43,44]$} \\
\hline & A-Raf & A-Raf binds and inhibits the pro-apoptotic kinase MST2 & human & {$[71,72]$} \\
\hline & \multirow[t]{3}{*}{ Raf-1/B-Raf } & Regulation and role of Raf-1/B-Raf heterodimerization & human & {$[51,53]$} \\
\hline & & $\begin{array}{l}\text { Mixed-lineage kinase } 3 \text { (MLK3) regulates B-Raf through maintenance of } \\
\text { the B-Raf/Raf-1 complex and inhibition by the NF2 tumor suppressor } \\
\text { protein }\end{array}$ & human & [55] \\
\hline & & $\begin{array}{l}\text { Diacylglycerol Kinase } \eta \text { Augments C-Raf Activity and } \\
\text { B-Raf/C-Raf Heterodimerization }\end{array}$ & human & {$[56]$} \\
\hline & PKK & $\begin{array}{l}\text { Protein kinase C-associated kinase (PKK, also known as RIP4/DIK) } \\
\text { lacking kinase activity can induce partial activation of NF } \kappa \mathrm{B}\end{array}$ & & [247] \\
\hline \multirow[t]{13}{*}{ CMGC } & ERK & $\begin{array}{l}\text { ERK (Extracellular signal-regulated kinase) acts as a transcriptional } \\
\text { repressor for interferon gamma-induced genes. }\end{array}$ & human & [89] \\
\hline & & $\begin{array}{l}\text { Catalytic Activation of the Phosphatase MKP-3 by ERK2 Mitogen- } \\
\text { Activated Protein Kinase }\end{array}$ & human & {$[86]$} \\
\hline & & $\begin{array}{l}\text { ERK Activates Topoisomerase Ilalpha through a Mechanism } \\
\text { Independent of Phosphorylation }\end{array}$ & mouse, human & [84] \\
\hline & & $\begin{array}{l}\text { ERK1/2 MAP kinases promote cell cycle entry by rapid, kinase- } \\
\text { independent disruption of retinoblastoma-lamin A complexes. }\end{array}$ & human & [91] \\
\hline & & $\begin{array}{l}\text { PARP-1 usually gets activated by DNA strand breaks and is required for } \\
\text { DNA repair. ERK } 2 \text { activates PARP-1 independently of DNA strand } \\
\text { breaks }\end{array}$ & rat & [85] \\
\hline & ERK3 & $\begin{array}{l}\text { ERK3, an atypical member of the MAPK family, interacts with MAPK- } \\
\text { activated protein kinase } 5 \text { (MK5 or PRAK) independent of ERK3 } \\
\text { enzymatic activity. Erk3 regulates MK5 cellular localization and } \\
\text { activation thus being involved in embryonic development. }\end{array}$ & mouse & [248] \\
\hline & ERK5/Mpk1 & $\begin{array}{l}\text { Erk5, a member of the MAPK family, associates with the Paf1 complex } \\
\text { thereby blocking Sen1-mediated premature transcription termination. }\end{array}$ & yeast, human & [249] \\
\hline & Erk8 & $\begin{array}{l}\text { Erk8 negatively regulates transcriptional co-activation of androgen } \\
\text { receptor and GRalpha by Hic-5 in a kinase-independent manner }\end{array}$ & & {$[250]$} \\
\hline & \multirow[t]{2}{*}{ p38 MAPK } & $\begin{array}{l}\text { p38 inhibits cell cycle progression in a kinase-independent fashion, } \\
\text { whereas promotes G2/M checkpoint in a kinase-dependent manner }\end{array}$ & $\begin{array}{l}\text { Several human and } \\
\text { murine cell lines }\end{array}$ & [98] \\
\hline & & $\begin{array}{l}\text { p38 blocks transcription in proliferating cells by sequestering } \\
\text { transcription co-activator Mirk/Dyrk1B }\end{array}$ & $\begin{array}{l}\text { NIH3T3/human cell } \\
\text { lines }\end{array}$ & [99] \\
\hline & Cdc2 & Cdc2 blocks cell cycle in S phase via inhibition of E2F & Drosophila & [251] \\
\hline & $\mathrm{Cdk} 1 / \mathrm{cdc} 28$ & $\begin{array}{l}\text { Cdk1/cdc28 recruits proteosomes to coding region to maintain } \\
\text { transcriptional activity }\end{array}$ & yeast & {$[252]$} \\
\hline & Cdk5 & Cdk5 is a cell cycle suppressor in normal post-mitotic neurons & $\begin{array}{l}\text { Mouse primary } \\
\text { neurons }\end{array}$ & [253] \\
\hline CK1 & Casein Kinase $1 \varepsilon$ & $\begin{array}{l}\text { Casein Kinase } 1 \varepsilon \text { regulates Fz/planar cell polarity (PCP) pathway in } \\
\text { Drosophila development in a kinase-independent manner, whereas } \\
\text { Wnt-Frizzled (Fz)/beta-catenin pathway requires its kinase activity }\end{array}$ & Drosophila & [254] \\
\hline & VRK-3 & $\begin{array}{l}\text { Vaccinia-related kinase } 3 \text { (VRK-3), a member of the VRK family, } \\
\text { suppresses ERK activity through direct binding to the MAPK } \\
\text { phosphatase Vaccinia H1-related (VHR). VHR is known to } \\
\text { dephosphorylate and inactivate ERK in the nucleus. }\end{array}$ & & [255] \\
\hline
\end{tabular}


Table 1 Catalytic-independent kinase functions according to the $\mathbf{7}$ major kinase groups (Continued)

\begin{tabular}{|c|c|c|c|c|}
\hline CAMK & AMPK & $\begin{array}{l}\text { AMP-activated protein kinase } \alpha \text { (AMPK } \alpha \text { ) acts as transcriptional co- } \\
\text { activator of PPAR under ATP deprivation }\end{array}$ & Rat hepatocytes & {$[256]$} \\
\hline & MARK2 & $\begin{array}{l}\text { MARK2 regulates neuronal morphology independently of kinase } \\
\text { activity }\end{array}$ & Neuronal cells & {$[257]$} \\
\hline & DAPK & $\begin{array}{l}\text { Death-associated protein kinase (DAPK) increases glycolytic rate } \\
\text { through binding and activation of pyruvate kinase }\end{array}$ & & {$[258]$} \\
\hline \multirow[t]{14}{*}{ STE } & MEK5 & $\begin{array}{l}\text { A constitutively active form of MEK5 is able to inhibit SUMOylation of } \\
\text { the atypical MAPK ERK5 independent of kinase activity, but dependent } \\
\text { on MEK5-ERK5 association }\end{array}$ & mouse & [259] \\
\hline & MEKK1 & $\begin{array}{l}\text { The PHD domain of MEKK1 acts as an E3 ubiquitin ligase and } \\
\text { mediates ubiquitination and degradation of ERK1/2 }\end{array}$ & human & [260] \\
\hline & $\begin{array}{l}\text { PAK1 (p21-activated } \\
\text { kinase1) }\end{array}$ & $\begin{array}{l}\text { Recruits Akt to the plasma membrane and facilitates Akt1 and PDK1 } \\
\text { interaction }\end{array}$ & $\begin{array}{l}\text { Cell lines including } \\
\text { Cos and } \mathrm{NIH} 3 \mathrm{T3}\end{array}$ & [136] \\
\hline & & $\begin{array}{l}\text { Overexpressed PAK1 induced lamellipodia formation and membrane } \\
\text { ruffling independently of its catalytic activity }\end{array}$ & REF52 cell line & [133] \\
\hline & & $\begin{array}{l}\text { PAK1 targeted to the plasma membrane promotes cell differentiation } \\
\text { in the PC12 model independently of its kinase activity }\end{array}$ & PC12 & [132] \\
\hline & & $\begin{array}{l}\text { Overexpressed PAK promotes F-actin accumulation in a kinase } \\
\text { independent manner, whereas its effect on cell shape is kinase- } \\
\text { dependent }\end{array}$ & Swiss $3 \mathrm{~T} 3$ & [134] \\
\hline & & $\begin{array}{l}\text { PAK1 promotes formation of multiprotein complex in focal adhesions } \\
\text { that consists of PAK-PIX-PKL-Paxillin. Conformational change, but not } \\
\text { kinase activity of PAK1 is required for complex formation }\end{array}$ & $\mathrm{CHO}$ cells & [135] \\
\hline & & $\begin{array}{l}\text { PAK1 induces activation of exchange factor, PIX, upon binding } G_{\beta \gamma} \text {. } \\
\text { This leads to Cdc42 activation and subsequently PAK1 kinase } \\
\text { activation. }\end{array}$ & Myeloid cells & [137] \\
\hline & PAK2 & PAK2 controls spindle orientation independently of its kinase activity & HeLa cells & [139] \\
\hline & PAK4 & $\begin{array}{l}\text { PAK4 mediates TNF } \alpha \text {-induced cell survival by promoting recruitment } \\
\text { of TRADD to TNF } \alpha \text { receptor }\end{array}$ & HeLa cells & [149] \\
\hline & & PAK4 promotes cell survival by inhibiting caspase activation & $\begin{array}{l}\text { Human (HeLa cells) } \\
\text { and mouse (NIH3T3) }\end{array}$ & {$[148,261]$} \\
\hline & $\begin{array}{l}\text { ASK1 } \\
\text { (MAP3K5) }\end{array}$ & $\begin{array}{l}\text { ASK1 inhibits NF- } \kappa \text { B-induced cell survival by perturbing TRAF6-TAK1 } \\
\text { interaction }\end{array}$ & HEK293 & {$[80]$} \\
\hline & & ASK1 induces a Daxx-dependent caspase-independent cell death & & [78] \\
\hline & MST1 & $\begin{array}{l}\text { MST1 serine-threonine kinase, a component of the RASSF1-LATS tumor } \\
\text { suppressor network, binds androgen receptor (AR), but the kinase } \\
\text { activity of MST1 is not involved in inhibition of AR. }\end{array}$ & human, mouse & [262] \\
\hline \multirow[t]{7}{*}{ AGC } & PDK1 & $\begin{array}{l}\text { Interacts with Ral-GDS and induces its GEF activity of in PI3 kinase } \\
\text { dependent manner }\end{array}$ & & [182] \\
\hline & & $\begin{array}{l}\text { Forms a multiprotein complex, required for NFkB activation upon TCR } \\
\text { activation in T cells }\end{array}$ & & [181] \\
\hline & Gprk2/GRK2 & $\begin{array}{l}\text { G protein-coupled receptor kinase } 2 \text { (Gprk2) promotes high-level } \\
\text { Hedgehog signaling by regulating the active state of Smo through } \\
\text { kinase-dependent and kinase-independent mechanisms in Drosophila }\end{array}$ & Drosophila & [263] \\
\hline & & $\begin{array}{l}\text { Kinase activity-independent regulation of the cyclin pathway by GRK2 } \\
\text { is essential for zebrafish early development. }\end{array}$ & Zebrafish & [264] \\
\hline & & $\begin{array}{l}\text { Interaction assays of the neurokinin-1 (NK-1) receptor with G-protein } \\
\text { coupled receptor kinases (GRKs) reveal that GRK5 interaction with the } \\
\text { receptor was dependent on intact kinase-activity, whereas the high } \\
\text { affinity phase of GRK2 interaction was independent of kinase activity. }\end{array}$ & & {$[265]$} \\
\hline & Gprk2 & $\begin{array}{l}\text { G Protein-coupled Receptor Kinase } 2 \text { (Gprk2) has kinase-independent } \\
\text { functions during Histamine H2 receptor desensitization }\end{array}$ & & {$[266]$} \\
\hline & MSK2 & $\begin{array}{l}\text { Mitogen- and stress-activated protein kinase } 2 \text { (MSK2), a member of } \\
\text { the ribosomal S6 kinase (RSK) family, functions as an adaptor in } \\
\text { mediating activation of PKR (double-stranded RNA (dsRNA)-activated } \\
\text { protein kinase) independent of its catalytic activity. }\end{array}$ & human & [267] \\
\hline Atypical & mTOR (FRAP) & $\begin{array}{l}\text { Differentiation of myoblasts can be rescued by Rapamycin-insensitive } \\
\text { or Rapamycin-insensitive kinase-dead mTOR }\end{array}$ & mouse & [192] \\
\hline
\end{tabular}


Table 1 Catalytic-independent kinase functions according to the $\mathbf{7}$ major kinase groups (Continued)

\begin{tabular}{|c|c|c|c|c|}
\hline & & Dystrophin expression muscle cells & mouse & [195] \\
\hline & & $\begin{array}{l}\text { Negative regulation of microRNA-125b expression in skeletal muscles } \\
\text { during differentiation and muscle regeneration }\end{array}$ & Mouse & {$[268]$} \\
\hline & Rad3 (ATR) & $\begin{array}{l}\text { Rad3 (ATR)-Rad26 (ATRIP) complex can recruit Tel1(ATM) to telomeres } \\
\text { independently of Rad3(ATR) kinase activity. }\end{array}$ & $\begin{array}{l}\text { Fission yeast } \\
\text { (Schizosaccharomyces } \\
\text { pombe) }\end{array}$ & {$[269]$} \\
\hline & Tel1 & ATM-related protein, Tel1, regulates telomere maintenance in yeast. & $\begin{array}{l}\text { Budding yeast } \\
\text { (Saccharomyces } \\
\text { cerevisiae) }\end{array}$ & {$[270]$} \\
\hline & $\mathrm{H} 11$ & $\begin{array}{l}\text { H11 has two functions in cardiac cells: At low doses, it induces } \\
\text { hypertrophy through kinase-independent activation of Akt, whereas at } \\
\text { high doses H11 causes apoptosis through protein kinase-dependent } \\
\text { mechanisms by inhibition of CK2. }\end{array}$ & mouse & {$[271]$} \\
\hline \multirow[t]{15}{*}{ Other kinases } & Wnk & $\begin{array}{l}\text { With-no-lysine (K) kinases (Wnk) regulate ion transport via both } \\
\text { catalytic and non-catalytic mechanisms. While regulation of cation- } \\
\text { chloride-coupled cotransporters, Na+-K+-2CI(-) cotransporter (NKCC) 1, } \\
\text { and NKCC2 by WNKs requires kinase activity, intersectin-mediated } \\
\text { endocytosis of ROMK1 is independent of Wnk kinase activity. }\end{array}$ & & {$[272]$} \\
\hline & & $\begin{array}{l}\text { Wnk1 mediates activation of SGK1 downstream to the Insulin-like } \\
\text { growth factor } 1 .\end{array}$ & & {$[200]$} \\
\hline & WNK2 & $\begin{array}{l}\text { Tumor suppressor as indicated by preventing colony formation in } \\
\text { glioma cells }\end{array}$ & & [273] \\
\hline & ILK & $\begin{array}{l}\text { ILK interaction with } \alpha \text {-parvin but not its kinase activity is required for } \\
\text { embryonic development }\end{array}$ & Mouse & {$[274]$} \\
\hline & & $\begin{array}{l}\text { ILK links the cytoskeleton and the plasma membrane at sites of } \\
\text { integrin-mediated adhesion. }\end{array}$ & Dosphila/C. Elegans & {$[275,276$} \\
\hline & & $\begin{array}{l}\text { ILK regulates actin reorganization in chondrocytes and modulates } \\
\text { chondrocyte growth independently of phosphorylation of Pkb/Akt and } \\
\text { GSK3-beta. }\end{array}$ & mouse & [277] \\
\hline & & $\begin{array}{l}\text { ILK regulates cell polarization, adhesion and actin accumulation at the } \\
\text { integrin-adhesion sites }\end{array}$ & mouse & {$[278]$} \\
\hline & & $\begin{array}{l}\text { ILK controls epidermis and hair follicle morphogenesis by modulating } \\
\text { integrin-mediated adhesion, actin reorganization, and plasma } \\
\text { membrane dynamics in keratinocytes }\end{array}$ & mouse & [279] \\
\hline & IKK $\alpha$ & $\begin{array}{l}\text { IKKa controls epidermis formation via regulation of keratinocyte } \\
\text { differentiation in a NF- } \kappa \text { B-independent fashion }\end{array}$ & mouse & {$[280]$} \\
\hline & IKK $\beta$ & $\begin{array}{l}\text { Regulates vascular permeability and migration of endothelial cells by } \\
\text { regulating Akt activation. }\end{array}$ & Endothelial cells & {$[281]$} \\
\hline & Aurora A/AIR-1 & $\begin{array}{l}\text { Aurora (AIR-1) stabilizes spindle microtubules independently of its } \\
\text { kinase activity, however kinase activity is required for centrosome } \\
\text { regulation }\end{array}$ & C. elegans & {$[282]$} \\
\hline & TLK-1 & $\begin{array}{l}\text { Tousled-like kinase (TLK-1) mediates activation of Aurora B kinases } \\
\text { independently of kinase activity thus regulating cell division }\end{array}$ & $\begin{array}{l}\text { Budding yeast } \\
\text { (Saccharomyces } \\
\text { cerevisiae) }\end{array}$ & {$[283]$} \\
\hline & $\mathrm{Fa} 2 \mathrm{p}$ & $\begin{array}{l}\text { Fa2p, a member of the NIMA-family of kinases (Neks), regulates cell } \\
\text { cycle by associating with the proximal end of centrioles. While this cell } \\
\text { cycle function of Fa2p is kinase independent, its function of } \\
\text { coordinating of cilia is kinase dependent. }\end{array}$ & $\begin{array}{l}\text { Chlamydomonas, } \\
\text { Kidney cells }\end{array}$ & [284] \\
\hline & Nek2B & $\begin{array}{l}\text { Nek2B, NIMA-related protein kinase, promotes assembly of a functional } \\
\text { zygotic centrosome independently of its kinase activity }\end{array}$ & Xenopus laevis & {$[285]$} \\
\hline & Apg1/Atg1 & $\begin{array}{l}\text { In autophagic cells, Apg1 (Ulk-1 in human) kinase activity is required } \\
\text { only for Cvt trafficking of aminopeptidase I but not for import via } \\
\text { autophagy. }\end{array}$ & yeast & {$[286]$} \\
\hline \multirow[t]{3}{*}{ Lipid kinases } & $\mathrm{p} 110 \beta$ & $\begin{array}{l}\text { The catalytic activity of p110 } \beta \text { is dispensable for embryonic } \\
\text { development }\end{array}$ & Mouse & {$[158]$} \\
\hline & & DNA replication during the $S$ phase & & {$[162]$} \\
\hline & & $\begin{array}{l}\text { Mediates double-strand DNA break repair via catalytic and non- } \\
\text { catalytic mechanisms }\end{array}$ & MEF and $\mathrm{NIH} 3 \mathrm{~T} 3$ & {$[161]$} \\
\hline
\end{tabular}


Table 1 Catalytic-independent kinase functions according to the 7 major kinase groups (Continued)

\begin{tabular}{|c|c|c|c|}
\hline & $\begin{array}{l}\text { Endocytosis and oncogenic transformation as indicated by transferin } \\
\text { uptake and foci formation, respectively. }\end{array}$ & MEF & [159] \\
\hline \multirow[t]{5}{*}{ p110y } & $\begin{array}{l}\text { p110y regulates integrin activation in platelets and thrombus } \\
\text { formation in a kinase-independent manner; p110 } \beta \text { contributes to the } \\
\text { same process by PIP3 production }\end{array}$ & Mouse & [287] \\
\hline & $\begin{array}{l}\text { Negatively regulates cardiac contractility by mediating } \\
\text { phosphodiesterase } 3 \mathrm{~B} \text { activation and thus leading to CAMP destruction }\end{array}$ & Heart (mouse) & [174] \\
\hline & $\begin{array}{l}\text { p110gamma binds phosphodiesterase 3B, whereas the regulatory } \\
\text { subunit of PI3K, p87 binds Protein Kinase A (PKA). PKA, activated by } \\
\text { cAMP phosphorylates phosphodiesterase } 3 \text { B and therefore leads to } \\
\text { negative regulation of cAMP levels in cardiomyocytes. }\end{array}$ & & [176] \\
\hline & Protective role during myocardial ischemia and reperfusion injury & $\begin{array}{l}\text { Endothelial progenitor } \\
\text { cells (mouse) }\end{array}$ & [169] \\
\hline & Reparative neovascularisation after unilateral limb ischemia & mouse & [168] \\
\hline \multirow[t]{3}{*}{ p85 } & Positivey regulates JNK activation in a response to insulin stimulation & brown adipose cells & [288] \\
\hline & $\begin{array}{l}\text { GTPase activity towards Rab4 and Rab5 small G proteins, as part of } \\
\text { negative PDGF regulation. Prevents cell transformation }\end{array}$ & & [289] \\
\hline & p85 controls mammalian cytokinesis by regulating Cdc42 activation & & [290] \\
\hline IP3K-A & $\begin{array}{l}\text { IP3K-A (Ins }(1,4,5) P(3) \text { 3-kinase-A) regulates cytoskeletal organization in a } \\
\text { kinase-independent manner }\end{array}$ & $\begin{array}{l}\text { Lung epithelial cells } \\
\text { (H1299) }\end{array}$ & [291] \\
\hline
\end{tabular}

AGC - Containing PKA, PKG, PKC families; CAMK - Calcium/calmodulin-dependent protein kinase; CK1 - Casein kinase 1; CMGC - Containing CDK, MAPK, GSK3, CLK families; STE - Homologs of yeast Sterile 7, Sterile 11, Sterile 20 kinases; TK - Tyrosine kinase (including receptor tyrosine kinases and non-receptor tyrosine kinases); TKL - Tyrosine kinase-like. (adapted from [2])

family members are found in $~ 30 \%$ of all epithelial cancers.

Interestingly, in cancer tissues the expression level of EGFR is correlated with prognosis, but not with responsiveness to EGFR inhibitor treatment [15]. This conundrum suggests that EGFR might contribute to tumor progression independently of its kinase activity. Several studies support this kinase-independent pro-survival function of the EGFR.

First, loss of the kinase activity of the EGFR does not produce phenotypes similar to the ablation of EGFR protein expression [16]. While EGFR knockout animals die soon after birth [17], animals expressing kinasedefective EGFR are viable and display only some epithelial defects [18].

Second, several groups reported the surprising results, that a kinase-defective EGFR was capable to activate downstream signalling (such as MAPK) and stimulate DNA synthesis, while failing to induce the tyrosine phosphorylation of endogenous substrates in response to EGF [19-22]. These kinase activity independent signalling included transcriptional effects, as kinase-deficient EGFR could activate c-fos expression [23]. The mechanism may include heterodimerization with other ERBB members. For instance, the co-expression of a kinase-inactive mutant of EGFR (K721M) with ERBB2 resulted in EGF-dependent Akt and MAPK activation., while kinase-inactive EGFR alone was ineffective [24]. ERBB2's kinase activity, but not tyrosine phosphorylation, was required for this activation. These results suggest that EGFR has catalytic-independent functions, which might be achieved by heterodimerization with other members of the ERBB receptor family.

More recent studies provide more mechanistic insights as to the nature of kinase-independent signalling, which relies on protein-protein interactions. In 2008, Weihua et al. reported that EGFR, independently of its kinase activity, prevents cancer cells from autophagic cell death by maintaining the basal intracellular glucose level [16]. EGFR interacts with and stabilizes the sodium/glucose cotransporter (SGLT1) in order to promote glucose uptake into cancer cells (Figure 2A). Interestingly, inhibition of the EGFR kinase activity did not block this association with SGLT1 or decrease basal intracellular glucose levels suggesting that no kinase activity is required for this regulation. Similarly, the EGFR and its constitutively activated variant EGFRvIII were shown to bind to and sequester the proapoptotic Bcl-2 family member PUMA in the cytoplasm leading to tumour drug resistance [25] (Figure 2B).

These results have important implications for therapeutic approaches relying on agents that inhibit the EGFR kinase activity, as the kinase independent functions of EGFR may open escape routes, which for instance maintain the viability of tumor cells even in the presence of EGFR kinase inhibitors.

In addition to non-catalytic functions regulating downstream effectors by the EGFR via direct protein interactions, they also contribute to the regulation of the localisation of the EGFR family itself. EGFR and other ERBB receptors are known to be regulated by endocytosis. Ligand binding induces the internalization 

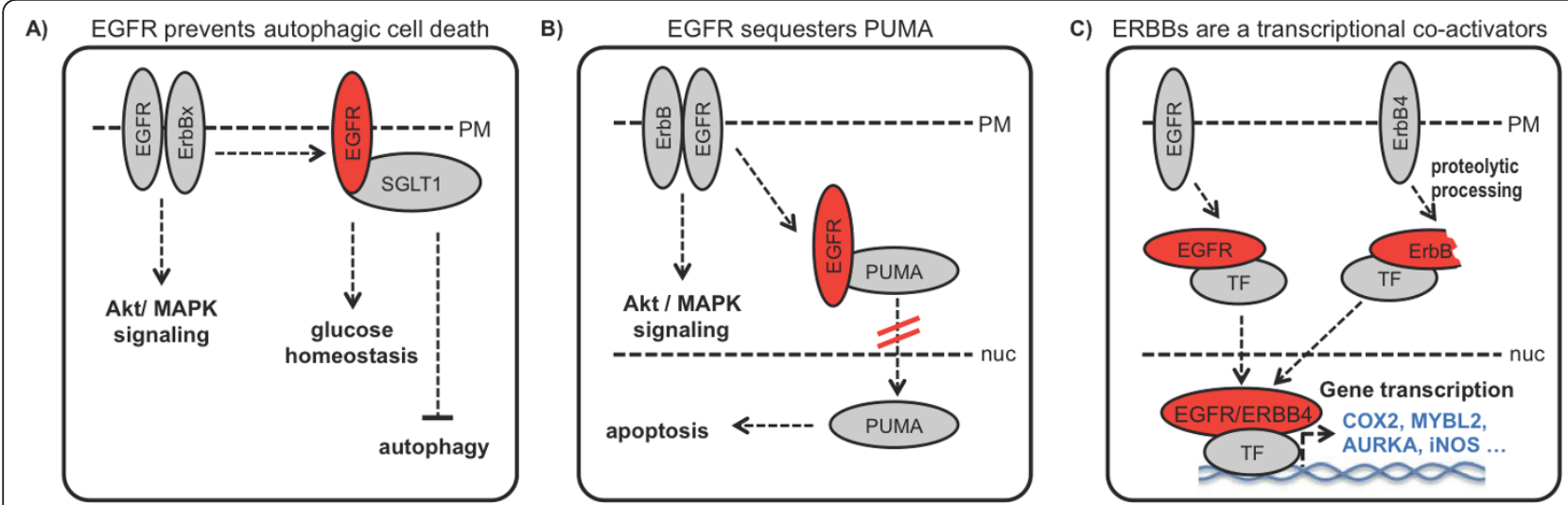

Figure 2 Kinase actitvity-independent functions of the EGFR/ERBBs. (A) EGFR prevents autophagic cell death by stabilizing the sodium/ glucose cotransporter (SGLT1) thus maintaining the basal intracellular glucose level. (B) In glioblastomas, EGFR and EGFR vill sequester the proapoptotic BCl-2 family member PUMA in the cytoplasm leading to tumour drug resistance. (C) EGFR and ERBB4 regulate gene expression by direct interaction with transcription factors in the nucleus.

of the receptor into endosomes, where the receptors are either targeted for ubiquitin-mediated degradation or recycled back to the plasma membrane. While this process was thought to require kinase activation, newer data suggest that rather than EGFR kinase activity, dimerization is necessary and sufficient for internalization [26].

ERBB family receptors contain nuclear localisation signals [27] enabling them to translocate to the nucleus, either as full length molecules (e.g. the EGFR) or as fragments (e.g. ERBB4) after proteolytic processing [28] (Figure 2C). Full-length EGFR trafficking from the plasma membrane seems to involve the Sec61 translocon [29], where upon addition of EGF the cell surface EGFR is trafficked to the endoplasmic reticulum. There, the EGFR associates with Sec61 $\beta$, and is subsequently retrotranslocated from the ER to the cytoplasm. The EGFR lacks a DNA binding domain, but can interact with several transcription factors, such as STATs $3 / 5$ and E2F1, to activate the expression of iNOS, COX-2, MYBL2 (B-Myb), and AURKA (Aurora A) genes [28]. As the induction of target gene expression could be inhibited by EGFR inhibitor drugs, gene transactivation seems to require catalytic EGFR activity. However, it is unclear whether kinase activity is needed for nuclear translocation or the actual transcriptional transactivation function of the nuclear EGFR. Interestingly, a C-terminal ERBB4 fragment lacking the kinase domain is able to activate transcription by associating with the YAP2 transcription factor [30], suggesting that the transactivation function may be independent of catalytic activity. Along these lines it has been suggested that the proteolytic ERBB4 fragment serves as a chaperone for STAT5 [31] and YAP [32] that facilitates nuclear entry of these transcription factors.
Kinase independent functions have been mainly described for the ERBB family, but may be more widespread in RTK signaling. This is not surprising given that the function of RTKs relies heavily on their abilities to assemble multi-protein signaling complexes. Although the focus has been on proteins recruited to tyrosine phosphorylation dependent docking sites, there is increasing evidence that a great number of proteins are associated with RTKs independently of ligand, and that at least some of these proteins also participate in the regulation of signaling [33].

\section{Insulin like Growth Factor-1 Receptor (IGFR)}

Another recent example for kinase independent signaling is the IGFR, which could stimulate the ERK pathway despite having its kinase activity blocked by chemical IGFR inhibitors or even abolished by mutation [34]. ERK activation also was independent of PI3K kinase activity or phosphorylation of IRS, which is a multivalent adaptor protein that mediates many of IGFR downstream signaling events. By contrast, ERK activation was blocked by chemical inhibition of Src family kinases or $G \beta / \gamma$ subunits of heterodimeric G-proteins, indicating that G-protein coupled receptor signaling participates in the kinase independent IGFR activation of ERK.

\section{Kinase independent functions of Mitogen Activated Protein Kinase (MAPK) pathway components}

MAPK pathways are ubiquitous signaling modules consisting of a three-tiered, and sometimes four-tiered, cascade of kinases that is activated by a small G-protein as input (Figure 3A). The name mitogen activated protein kinase is historic, but now indicates a range of pathways that respond to a variety of stimuli including mitogens, hormones, and stress signals [35]. The activation of the first kinase, MAPKKK, is initiated by it binding to an 


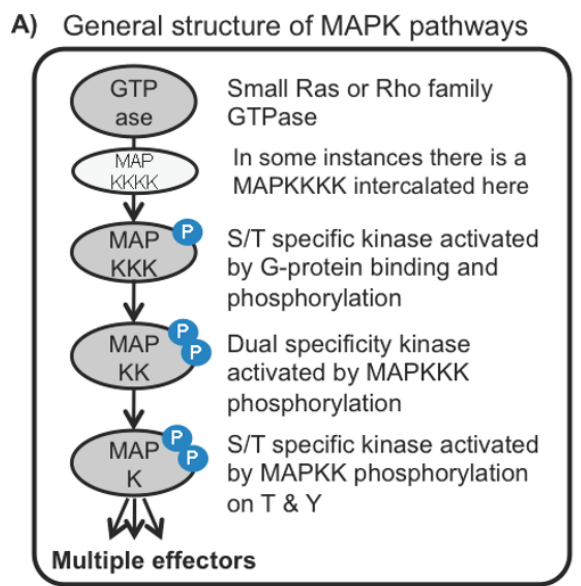

C) Raf-1 controls apoptosis via ASK1

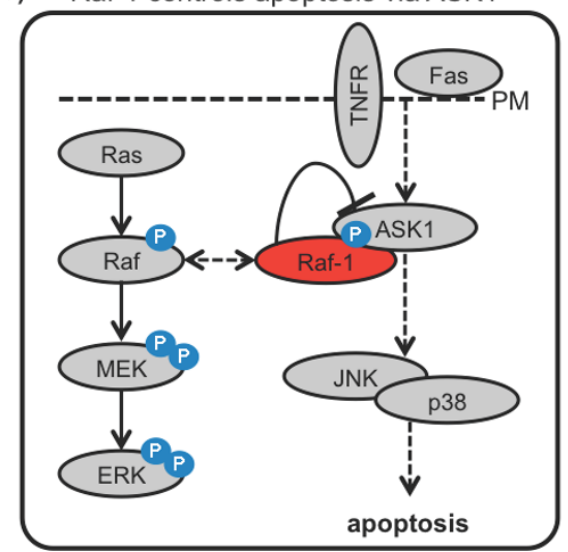

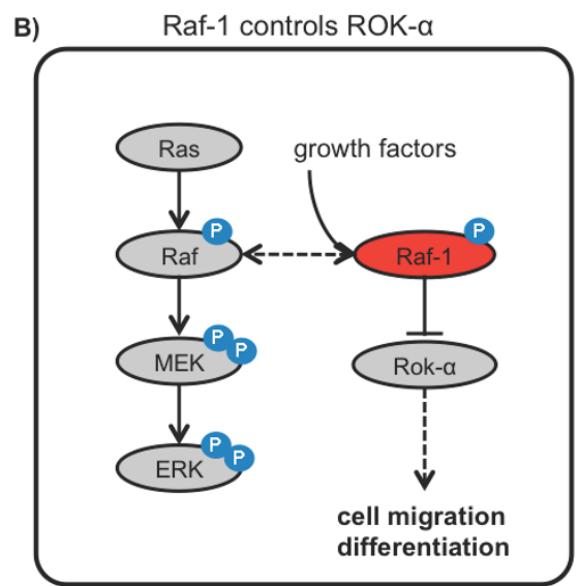

D) Raf inhibits proapoptotic MST2 signaling

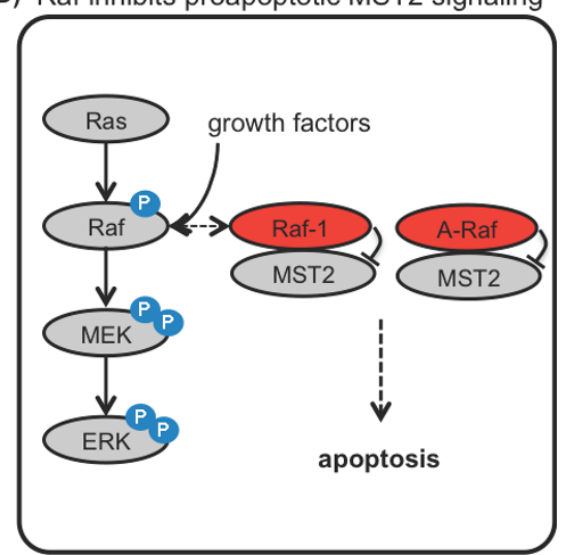

Figure 3 Kinase-independent functions of Raf kinases. (A) General structure of MAPK pathways. (B) Raf-1 controls cell migration and differentiation by inhibiting the Rho effector kinase ROK- $\alpha$. (C) Raf-1 controls TNF- and Fas-mediated apoptosis by inhibiting apoptosis signalregulating kinase-1 (ASK). (D) Raf-1 and A-Raf bind and inhibit the pro-apoptotic mammalian sterile 20-like kinase (MST2) thereby interfering with its dimerization, autophosphorylation, and activation.

activated Ras or Rho family protein. MAPKKK then phosphorylates and activates MAPKK, which are dual specificity kinases that activate MAPK by phosphorylation of a tyrosine and threonine in the activation loop. While signaling within the cascade is largely linear, the terminal MAPK usually has a large number of substrates, whose phosphorylation kinetics and localization contribute to the generation of specific biological outputs $[35,36]$. The design of MAPK modules conveys interesting intrinsic properties, such as switchlike responses and output stabilization $[37,38]$.

\section{Kinase independent functions of Raf kinases}

Raf is the MAPKKK in the first MAPK pathway identified, the Ras-Raf-MEK-ERK pathway. This cascade is a main effector pathway of ERBB receptors, and altered in a high percentage of cancers usually be mutation of Ras or BRAFgenes. ERK features more than 150 substrates thereby regulating many fundamental cellular functions, including proliferation, differentiation, transformation, apoptosis and metabolism [39].

Raf proteins come in three isoforms (A-Raf, Raf-1, BRaf) encoded by different genes. A wealth of experimental data suggests that MEK1 and MEK2 are the only bona fide Raf substrates. B-Raf has the strongest kinase activity towards MEK, while Raf-1 is weaker and A-Raf activity is barely detectable [40]. From an evolutionary point of view and phylogenetic comparisons, the single Raf homologs in invertebrates (lin-45 in Caenorhabditis elegans and D-Raf in Drosophila melanogaster) are much closer related to B-Raf in terms of sequence, than Raf- 1 and A-Raf $[41,42]$. This suggests that B-Raf is the archetypal MEK kinase, whereas A-Raf and Raf- 1 may have evolved towards MEK-independent functions. Furthermore, gene ablation experiments in mice showed that Raf- 1 is required for survival and protects against apoptosis $[43,44]$. Of note, reconstituting $R a f-1^{-/}$mice 
with a non-activatable Raf-1 mutant with reduced kinase activity fully rescued the apoptotic phenotype and produced viable mice [43]. Taken together, these results suggested, that Raf-1 (and A-Raf) might possess kinaseindependent functions. During the hunt for new Raf targets, new kinase-independent roles for Raf proteins besides the MEK substrate have emerged. These include the regulation of cell motility and differentiation by controlling the activity of ROK- $\alpha$ and the regulation of apoptosis by suppressing the activity of the proapoptotic kinases ASK1 and MST2, none of which requires Raf-1 kinase activity (reviewed in [45-47]).

Raf heteromers Over the years it emerged that Raf proteins are able to homo- and heterodimerize with each other [48-50]. Interestingly, these allosteric mechanisms of dimerization regulate kinase activity of the complexes. One intriguing phenomenon was that even a catalytically compromised B-Raf was capable of inducing kinase activity of Raf-1 in trans in a manner dependent on a physical interaction between B-Raf and Raf-1, suggesting that the underlying mechanism is independent of a simple transautophosphorylation route [46,51-53]. Only recently, the exact mechanism of how these dimers are regulated was discovered [54], which suggests that two Raf proteins are found in a 'side-to-side' dimer configuration. Several proteins seem to be responsible for the correct configuration, which include the scaffold KSR and 14-3-3 proteins [54]. Additionally, two kinases, MLK3 and DGK $\eta$ can enhance and maintain Raf-1/BRaf heterodimer formation independently of their kinase activity $[55,56]$. What has not been solved yet is the mechanism how a kinase dead Raf protein can stimulate the activity of another Raf protein in the context of a heterodimer, but an allosteric mechanism is the most plausible possibility. The observation that Raf- 1 activation by heterodimerization with B-Raf seems to proceed differently from the activation used by growth factors [51], is in keeping with such an alternative mechanism of Raf activation exerted by allosteric changes. Interestingly, Raf-1 and B-Raf also can induce allosteric conformation changes in KSR, which conveys KSR the ability to phosphorylate MEK $[57,58]$. KSR is scaffolding protein that binds Raf, MEK and ERK, but whether KSR also has kinase function is controversial with most evidence indicating that at least mammalian KSR proteins lack kinase activity [59]. Although, in vitro MEK phosphorylation by KSR is weak and mainly occurs on sites different from the known activating sites [57], work with KSR1 knockout cells has suggested that KSR1 is required for efficient ERK pathway activation in cells [58]. This enhancement may reflect allosteric cooperativity between Raf and KSR, and maybe other MEK kinases, when assembled into multi-protein complexes in cells. This kind of complex formation may also play a pathophysiological role in cancer. It could explain the surprising finding that a small number of B-Raf mutations occurring in tumors have reduced kinase activity, and exert their oncogenic action by stimulating Raf-1 [52]. A therapeutically even more important observation is that Raf inhibitory drugs can activate the ERK pathway, and in clinical trials may be responsible for some adverse side effects of otherwise highly efficacious Raf inhibitors [60,61]. This paradoxical activation of ERK occurs in tumor cells with Ras mutations, which cooperate with Raf inhibitors to induce B-Raf-Raf-1 heterodimerization [62]. As the Raf heterodimer activates MEK at least 30-fold stronger than B-Raf, but only requires one Raf partner to have kinase activity [53], even a slightly incomplete inhibition of Raf will promote ERK pathway activation by Raf heterodimers.

$R O K-\alpha$ ROK $-\alpha$ is a direct effector of the Rho GTPase, which is activated by binding to active Rho [63]. In Raf1 knockout cells ROK- $\alpha$ is hyperactivated and mislocalized to the membrane $[64,65]$. Furthermore, Raf-1mediated inhibition of ROK- $\alpha$ promotes cell migration and reduces sensitivity to Fas-induced apoptosis $[64,65]$. Stimulation with growth factors induces an interaction between the regulatory region of Raf- 1 and the kinase domain of ROK- $\alpha$, resulting in inhibition of ROK- $\alpha$ kinase activity [66] (Figure 3B). This in trans regulation of a kinase domain by the regulatory domain of another kinase introduces a new concept of kinase regulation that may have important implications for signal coordination where the activation of one pathway automatically would inhibit another pathway. In a more recent study, Raf-1-mediated inhibition of ROK- $\alpha$ was shown to block keratinocyte differentiation, thus allowing both the development and maintenance of Ras-driven epidermal tumors in mice $[47,67]$. Of interest, the regulation of ROK- $\alpha$ by Raf- 1 is exclusively mediated by proteinprotein interactions and does not require Raf-1 kinase activity.

MST2 The other proapoptotic kinase, which is inhibited by Raf-1, is mammalian sterile 20-like kinase, MST2, which was identified in a proteomics screen of Raf-1associated proteins [68]. MST2 is activated by dimerization and autophosphorylation of the activation loop. Raf-1 interferes with MST2 dimerization and autophosphorylation by binding to the MST2 SARAH domain, which mediates MST2 dimerization (Figure 3D). Raf-1 kinase activity is not required for this regulation as kinase-dead Raf-1 mutants, or even the mutant lacking the complete kinase domain, also can inhibit MST2 activation. As a result, MST2 activity is constitutively elevated in Raf-1 knockout cells and hyperactivatable by Fas stimulation or expression of RASSF1A $[68,69]$. Interestingly, the Raf-1-MST2 interaction is induced by stress and relieved by mitogens. Upon stimulation of 
cells, Ras binding to Raf- 1 enables Raf-1 to activate the ERK pathway and promote proliferation, but at the same time dissociates the MST2-Raf-1 complex and promotes apoptosis [70]. Coupling cell proliferation to the risk of cell death seems paradoxical at first sight, but this dual role makes perfect sense for higher organisms where the uncontrolled proliferation of cells can lead to severe diseases including cancer. In a subsequent study, we could show that A-Raf, the third member of the Raf family, also binds to and inhibits MST2 [71,72]. Similar to Raf-1, A-Raf kinase activity is not required as kinasedead A-Raf mutants also can inhibit MST2 activation. However, while Raf-1 binding to MST2 is induced by stress and reduced by mitogens, A-Raf binds to MST2 constitutively and seems to promote the survival of cancer cells by restraining MST2 mediated apoptosis [71]. B-Raf binds MST2 only very weakly [68]. Thus, the observed differential MST2 binding pattern inversely correlates with the kinase activity towards MEK and the evolution of the Raf family. B-Raf as the oldest member possesses the strongest MEK kinase activity and the lowest affinity for MST2, while the youngest member, A-Raf, has the poorest MEK kinase activity but the strongest capacity to bind and inhibit MST2 [72]. This observation suggests that during evolution the role of Raf might have shifted from activating the ERK pathway to inhibiting the MST2 pathway.

From a therapeutic point of view, targeting these catalytic-independent Raf interactions (ROK-alpha, ASK1, MST2) in cancer might prove to be a good strategy. Disruption of Raf-1/ROK-alpha might provoke the differentiation of epidermal skin tumor cells, while the dissociation of Raf-1/A-Raf from ASK1 and MST2 should activate these kinases to cause apoptosis in tumor cells.

ASK1 Another kinase, which is regulated by Raf-1 independent of its catalytic activity is apoptosis signal-regulating kinase-1 (ASK) (Figure 3C). ASK1 works as a MAPKKK in the JNK and p38 MAPKs pathways to promote apoptosis induced by stress or by death receptors, such as the TNF- receptor or Fas [73]. Raf-1 binds to ASK1 inhibiting its kinase activity and apoptosis. Raf-1 catalytic activity was not required for the control of ASK1 as a kinase dead Raf-1 mutant inhibited ASK1 as potent as wildtype Raf-1 [74]. Although the direct mechanism of inhibition is not known yet, the pathophysiological relevance of ASK1 inhibition by Raf-1 was demonstrated in a mouse model of heart disease [75]. A tissue-specific knockout of the $R a f-1$ gene in the heart muscle resulted in ventricular dilation and fibrosis caused by an increase in cardiomyocyte apoptosis. These pathological changes could be prevented by also knocking out the ASK1 gene.

Interestingly, ASK1 is able to induce apoptosis in a kinase activity dependent and independent manner. The kinase dependent way executes apoptosis via the activation of JNK and subsequent inactivation of Bcl-2 [76] and stabilization c-Myc [77]. The kinase independent pathway induces a caspase-independent form of cell death, which is enhanced by the binding of ASK1 to Daxx [78]. The contribution of this kinase independent pathway to ASK1 induced cell death still needs to be clarified, as it relied on the overexpression of ASK1 or kinase defective mutants. In addition, Daxx is an activator of the ASK1 kinase activity, and Daxx induced apoptosis was reported to be blocked by a kinase deficient ASK1 mutant [79]. Another potential target of kinase-independent ASK1-induced apoptosis is the transcription factor nuclear factor-kappaB (NFB), a key regulator of immune and inflammatory responses that exerts anti-apoptotic roles in various cells. ASK1 directly interacts with TAK1 (transforming growth factor-beta-activated kinase 1), a kinase involved in NFB activation in response to inflammatory and cytokine signalling. ASK1inhibits NFB activation by interfering with the formation of the TRAF6/TAK1 complex that mediates interleukin-1 induced TAK1 activation [80]. This disruption renders cells vulnerable to apoptosis upon inflammatory stress.

\section{ERK MAPK}

ERK1 and ERK2 are the MAPKs at the end of this pathway featuring more than 150 known substrates, and it is still far from clear how these diverse functions are coordinated in order to achieve the intended biological outcome and specificity [39]. Besides their canonical kinase dependent functions, both ERK kinases were shown to influence their substrates not only by phosphorylation, but also by direct protein-protein interactions independently of ERK kinase activity [81-83]. There are only few examples, but as ERK tends to associate with its substrates in rather stable pre-activation complexes [36] this type of regulation may be more widespread than currently appreciated.

One example is topoisomerase IIa, an enzyme involved in winding and unwinding of DNA and therefore crucial in replication and transcription. Shapiro and co-workers reported that topoisomerase IIa is activated by ERK by a phosphorylation-independent process [84]. The exact mechanism of this activation is not clear. Interestingly, it requires a double phosphorylated ERK protein that is in the activated conformation, but it does not rely on ERK kinase activity itself. ERK is likely to induce a conformational change of the topoisomerase by a direct interaction, thus leading to the expected regular DNA unwinding activity of the topoisomerase [84].

Another interesting kinase independent target of ERK2 is PolyADP-ribose polymerase 1 (PARP-1), where no kinase activity of ERK is required. PARPs catalyze the posttranslational modification of nuclear proteins by polyADP-ribosylation. Usually, the catalytic activity of PARP-1 is stimulated by DNA strand breaks, and its activation is 
required for initiation of DNA repair. Cohen-Armon and co-workers report an alternative mode of activation [85], where ERK2 interacts with PARP-1 and activates it independent of DNA strand breaks Figure 4B). Of note, these findings indicate that while phosphorylation of ERK is required for the interaction and activation of PARP-1, no kinase activity of ERK2 is necessary for this process.

Another example is an enzyme that dephosphorylates ERK, the phosphatase MKP3, which negatively regulates ERK activation [86]. MKP3 directly interacts with ERK through a region of the phosphatase termed kinase interaction motif (KIM). Interestingly, this interaction is independent of the phosphorylation status of ERK and its kinase activity, as phosphorylation of the activating residues of ERK does not induce a dissociation of the ERKMKP3 complex. However, this interaction enhances the phosphatase activity of MKP3. In addition, MKP3 is a mitogen induced gene and located in the cytosol [87]. These traits indicate that the association of MKP3 with ERK also could be involved in a feedback regulation that eventually shifts ERK activity to the nucleus. Thus, MKP3 may not only function as inhibitor, but rather shape spatiotemporal gradients of ERK activation. This hypothesis needs further testing, but recent studies point to an important role of MKPs to regulate spatiotemporal aspects of ERK signaling [88].

Non-catalytic functions of ERK2 can be also linked with interferon signaling [89]. ERK2 was surprisingly identified in a large screen as a DNA-interacting protein. ERK binding to DNA was independent of kinase activity, direct, and to a specific DNA sequence, GAAAC, found in the promoters of interferon- $\gamma$ (INF $\gamma$ ) responsive genes. This sequence motif is also bound by the C/EBP- $\beta$ transcription factor, and ERK2 acted as a transcriptional repressor by

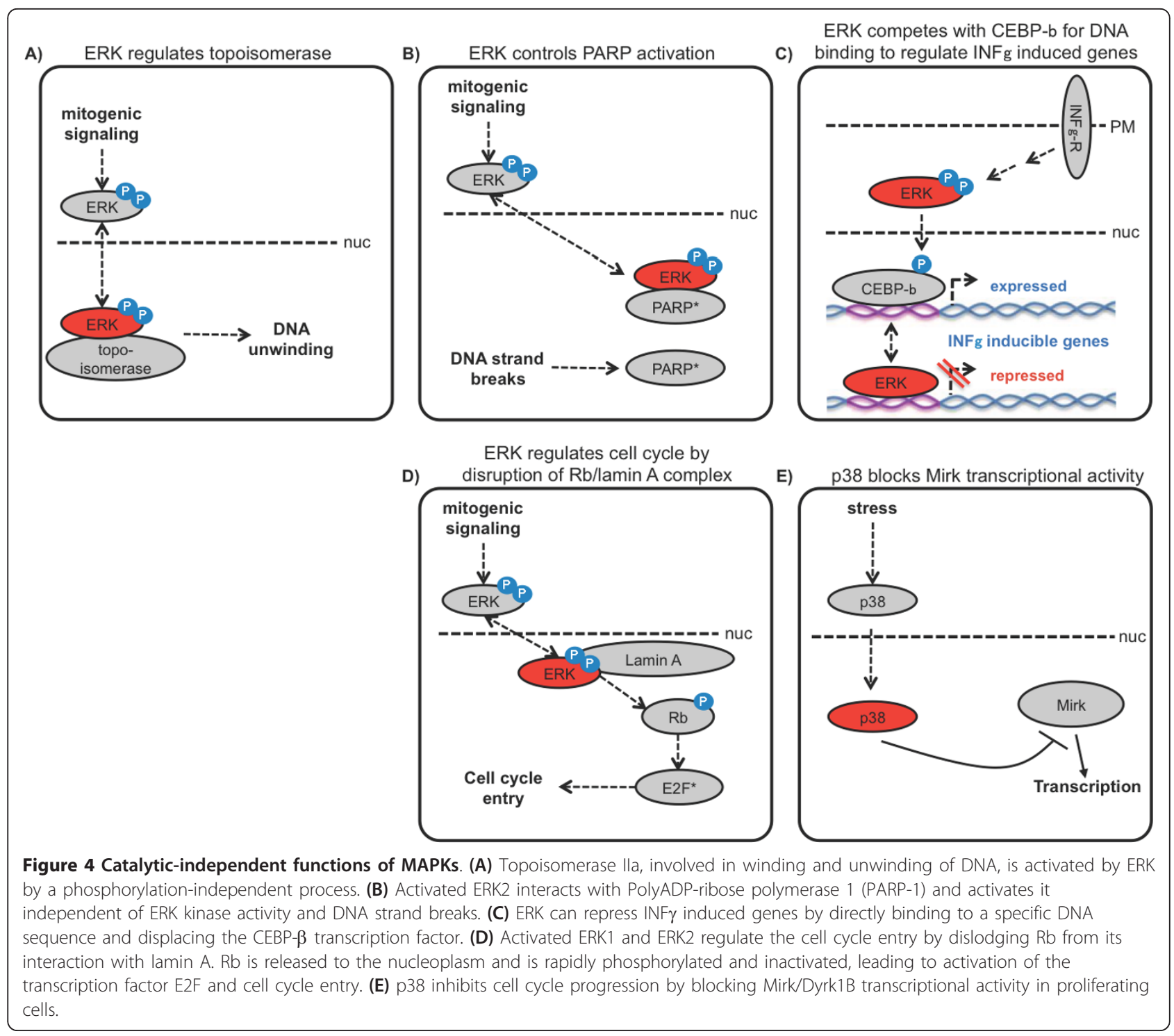


competing with C/EBP- $\beta$ for DNA binding (Figure 4C). In addition, kinase independent and dependent ERK functions may collaborate to form autoregulatory feedback loops. In the case of INF $\gamma$ responsive genes, ERK can repress their transcription by direct DNA binding. However, when ERK becomes activated it can phosphorylate C/EBP- $\beta$ which displaces ERK from the DNA and stimulates gene transcription. The increase in nuclear ERK caused by ERK activation eventually can dislodge C/EBP- $\beta$ from the promoter again and terminate transcription. The transcriptional induction of MKPs, which deactivate ERK by dephosphorylation, ensures that C/EBP- $\beta$ activation by ERK also ceases. This ability to regulate gene transcription by direct DNA binding highly increases the number of ERK targets.

This theme of competing for critical binding sites is reiterated in the context of cell cycle regulation by the ERK pathway. ERK kinase activity is crucial for promoting cell cycle entry by various mechanisms including the induction of cyclin D1, stabilization of c-Myc and regulation of cell cycle inhibitors such as $\mathrm{p} 21^{\text {waf/cip }}$ and $\mathrm{p} 27^{\mathrm{kip}}$ [90]. A kinase independent component was only recently discovered [91]. Lamin A, an integral part of the nuclear matrix and involved in the stabilization of chromatin structure and regulation of gene expression, was shown to be a mutually exclusive docking protein for ERK1/2 and the retinoblastoma $(\mathrm{Rb})$ protein (Figure 4D). When ERK1/2 becomes activated and enters the nucleus, ERK1/2 dislodges Rb from its interaction with lamin $\mathrm{A}$. $\mathrm{Rb}$ released to the nucleoplasm is rapidly phosphorylated and inactivated, leading to the activation of the transcription factor E2F and cell cycle entry. No kinase activity from either ERK1 or ERK2 was necessary for these processes [91].

\section{p38 MAPK}

The mammalian p38 subfamily of MAPKs comprises 4 members $(\alpha, \beta, \gamma$ and $\delta)$ that are differentially expressed in various tissues, and activated in response to a wide range of extracellular stress stimuli, including cytokines and growth factors [92]. Numerous data obtained from mouse knockout studies and selective pharmacological inhibitors implicate an important role of p38 $\alpha$ MAPK in inflammatory and immune responses [93-95]. More recent studies show that the mammalian p38 MAPK pathway behaves as a cell cycle inhibitor in both G1/S and G2/M checkpoint controls in response to stress stimuli $[96,97]$. Whereas the role of p38 in cell cycle regulation was clearly established, some of these functions may not require p38 catalytic activity. For instance, p38 $\alpha$ depletion, but not its specific pharmacologic inhibition, impeded cell proliferation and caused mitotic arrest, revealing p38 $\alpha$ functions independent of its kinase activity [98]. Moreover, these phenotypes were reversed by the ectopic expression of a kinase-dead p38 $\alpha$ mutant. Finally, overexpression of wild type or kinase-negative p38 $\alpha$ also strongly inhibited cell proliferation, proving that $\mathrm{p} 38 \alpha$ also has a key kinase-independent function [98]. However, despite the clear absence of requirement for $\mathrm{p} 38$ catalytic activity to regulate cell cycle progression, the exact mechanism used to achieve this function is unknown.

Mirk/Dyrk1B protein kinase is a potential candidate to explain a kinase-independent role of p38 in cell cycle regulation (Figure 4E). Mirk functions as a transcriptional activator of genes involved in the response to certain stress agents [99]. Co-immunoprecipitation experiments demonstrated that both wild type and kinase-inactive p38 bind to Mirk and prevent its association with upstream activators and transcriptional co-factors. Interestingly, this effect is isoform specific, as only the $\mathrm{p} 38 \alpha$ and $\mathrm{p} 38 \beta$, but not the $\gamma$ or $\delta$ isoforms, bind to Mirk. In addition, the observation that Mirk protein levels were variable while p38 levels stayed constant suggested that endogenous p38 could only block Mirk function when Mirk levels were low (S phase) and not when Mirk levels were elevated $\left(G_{0} / G_{1}\right)$ [99]. These observations emphasized a novel cell cycle-dependent function for $\mathrm{p} 38$, suppressing Mirk transcriptional activity in a kinase-independent fashion only when cells are proliferating.

\section{Kinase independent functions in regulating cell adhesion and migration Src}

Src belongs to a family of eight non-receptor tyrosine kinases and is implicated in a wide variety of signal transduction pathways. Src proteins regulate many fundamental cellular processes, such as proliferation, differentiation, cell shape, migration and apoptosis [100-102]. These pleiotropic functions of the Src family explain the importance of these kinases within the signalling machinery, and it comes as no surprise that most members of this family have been identified as oncogenes [103]. Src proteins feature a modular structure of three domains, the N-terminal SH3 domain, the central $\mathrm{SH} 2$ domain and a tyrosine kinase domain. The $\mathrm{SH} 2$ and $\mathrm{SH} 3$ domains cooperate in regulating the auto-inhibition of the kinase domain. Additionally, an inhibitory tyrosine phosphorylation in the C-terminus acts a binding site for the $\mathrm{SH} 2$ domain, which locks the protein in a closed conformation, and further facilitates binding of the $\mathrm{SH} 3$ domain to a linker region between the $\mathrm{SH} 2$ and kinase domain. This architecture allows for multiple mechanisms for c-Src activation, either by dephosphorylation of the $\mathrm{C}$-terminal tyrosine by protein tyrosine phosphatases or competitive binding to the $\mathrm{SH} 2$ and $\mathrm{SH} 3$ domains by other proteins. The list of Src family kinase substrates is long $[104,105]$, but here we briefly discuss targets of Src, which are regulated in kinase independent way.

Activation of integrin signalling is associated with a transient increase in Src kinase activity and translocation of Src to the focal adhesion complex and subsequent 
phosphorylation of focal adhesion kinase (FAK) [106-108]. Src-deficient fibroblasts were shown to have defects in cell spreading which is presumably related to the activation of Src by integrins. Complementation of this phenotype does not require kinase activity of Src, as cell spreading is restored by either wild type or kinasedefective Src [109]. In a similar fashion, activation of the Src-dependent adaptor protein pp $130^{\mathrm{CAS}}$ in fibroblasts in response to fibronectin binding does not require $\mathrm{Src}$ kinase activity [110]. Overexpression of Src in human colon cancer cells induces FAK phosphorylation on several tyrosine residues. Surprisingly, only one phosphorylation site requires the catalytic activity of Src, whereas phosphorylation on four other sites requires the intact $\mathrm{SH} 2$ domain of Src but not its catalytic activity [111]. Ablation of both Src alleles in the mouse causes osteopetrosis due to an intrinsic defect in osteoclasts [112]. Surprisingly, re-expression of kinase-defective version of $c$-Src led to a reduction in osteopetrosis in $\mathrm{Src}^{-1-}$ animals and partially rescued a defect in cytoskeletal organization observed in $\mathrm{Src}^{-1-}$ osteoclasts. These results suggest that no kinase activity is required for this phenotype.

These results suggest important kinase independent functions of Src in integrin signalling and cytoskeletal organization. This is not surprising given that they strongly rely on spatial organization, which may be better suited to be negotiated by protein interactions rather that catalytic activities.

However, while cytoskeletal organization is the prime paradigm for kinase independent Src family functions, there is also evidence for kinase independent signalling in other roles. These examples include the organisation of multiprotein signalling complexes in signalling by cytokines [113], the T-cell receptor [114], and the B-cell receptor [115]. The evidence is sparse but consistent, suggesting that we are far from having fathomed the kinase independent functions of Src family kinases.

\section{Focal Adhesion Kinase (FAK)}

FAK is a tyrosine kinase mediating integrin signalling and also participating in signal transduction by growth factor receptors [116,117]. FAK contains an N-terminal FERM (band 4.1, ezrin, radixin, moesin homology), a kinase and a C-terminal FAT (focal a FAT domain links FAK to integrins and focal adhesions, whereas the FERM domain connects FAK to membrane growth factor receptors and is also responsible for nuclear translocation. Early reports suggested that FAK could play a scaffolding role mediating crosstalk between signalling pathways. Indeed, FAK has been shown to induce anchorage-dependent JNK activation in a kinase-independent fashion by interacting with paxillin [118]. The exact mechanism is not known but seems to rely on FAK promoting paxillin localization to the cell membrane and the recruitment of paxillin kinase linker (PKL) and PAK-Interacting exchange Factor (PIX) [119], a guanine nucleotideexchange factor (GEF) that activates Rac, which in turn activates the JNK pathway $[120,121]$ (Figure 5A). Interestingly, JNK phosphorylation of S178 in paxillin enhances the binding of FAK to paxillin [122] creating a positive feedback loop that could promote the accumulation of paxillin at focal adhesions.

Importantly, FAK plays a crucial role in vascular development, and mice lacking FAK in their vascular system die before birth due to defects in angiogenesis and apoptosis of endothelial cells [123]. Mice expressing a kinasedeficient FAK mutant selectively in endothelial cells still died before birth, but the embryos survived longer than animals without any FAK in their vascular system [124]. Expression of kinase-dead FAK did not correct the vessel malformation, but enhanced endothelial cell survival by a mechanism involving the downregulation of the cyclindependent kinase inhibitor $\mathrm{p} 21^{\text {waf/cip }}[124]$. $\mathrm{p} 21^{\text {waf/cip }}$ was one of the first p53 target genes identified [125]. FAK inactivation during mouse development results in p53- and p21-dependent mesodermal cell growth arrest. By creating $\mathrm{FAK}^{-1-} \mathrm{p}^{2} 1^{-1-}$ double knockout fibroblasts Lim et al. [126] showed that FAK, in a kinase-independent fashion, causes p53 instability via enhanced Mdm2-dependent p53 ubiquitination (Figure 5B). p53 inactivation required the FAK FERM domain for nuclear localization, p53 binding and connections to $\mathrm{Mdm} 2$, the $\mathrm{p} 53$ specific ubiquitin ligase responsible of p53 degradation. These observations defined a scaffolding role for nuclear FAK in facilitating cell survival through enhanced p53 degradation [126].

Pyk2 is a cytoplasmic tyrosine kinase related to FAK and sharing similar domain structure. Interestingly, compensatory Pyk2 expression was observed in $\mathrm{FAK}^{-/-}$mice [127], suggesting some redundancy between FAK and Pyk2 functions. Indeed, FAK knockdown induced p53 activation and cell cycle arrest in endothelial cells, but a subsequent increase in Pyk2 expression led to p53 downregulation and the release of cell cycle block [128]. Moreover, in $\mathrm{FAK}^{-1-} \mathrm{p} 21^{-1-}$ double knockout mouse embryo fibroblasts, an increase of p53 levels associated with inhibition of cell proliferation was observed only when Pyk2 was downregulated [128]. Thus, similar as FAK, Pyk2 promotes Mdm2dependent p53 ubiquitination to facilitate cell proliferation and survival in a kinase-independent manner (Figure 5B).

\section{PAK}

p21-activated kinase 1 (PAK1) is a serine/threonine kinase belonging to the highly homologous group I of PAKs (PAKs 1-3). PAK1-3 activation is mediated by Rho family small $\mathrm{G}$ proteins, including Rac and $\mathrm{Cdc} 42$, which bind PAKs and induce its conformational change leading to exposure and activation of the catalytic domain [129]. PAKs are associated with a wide variety is cellular functions, including regulation of the MAPK pathway, 


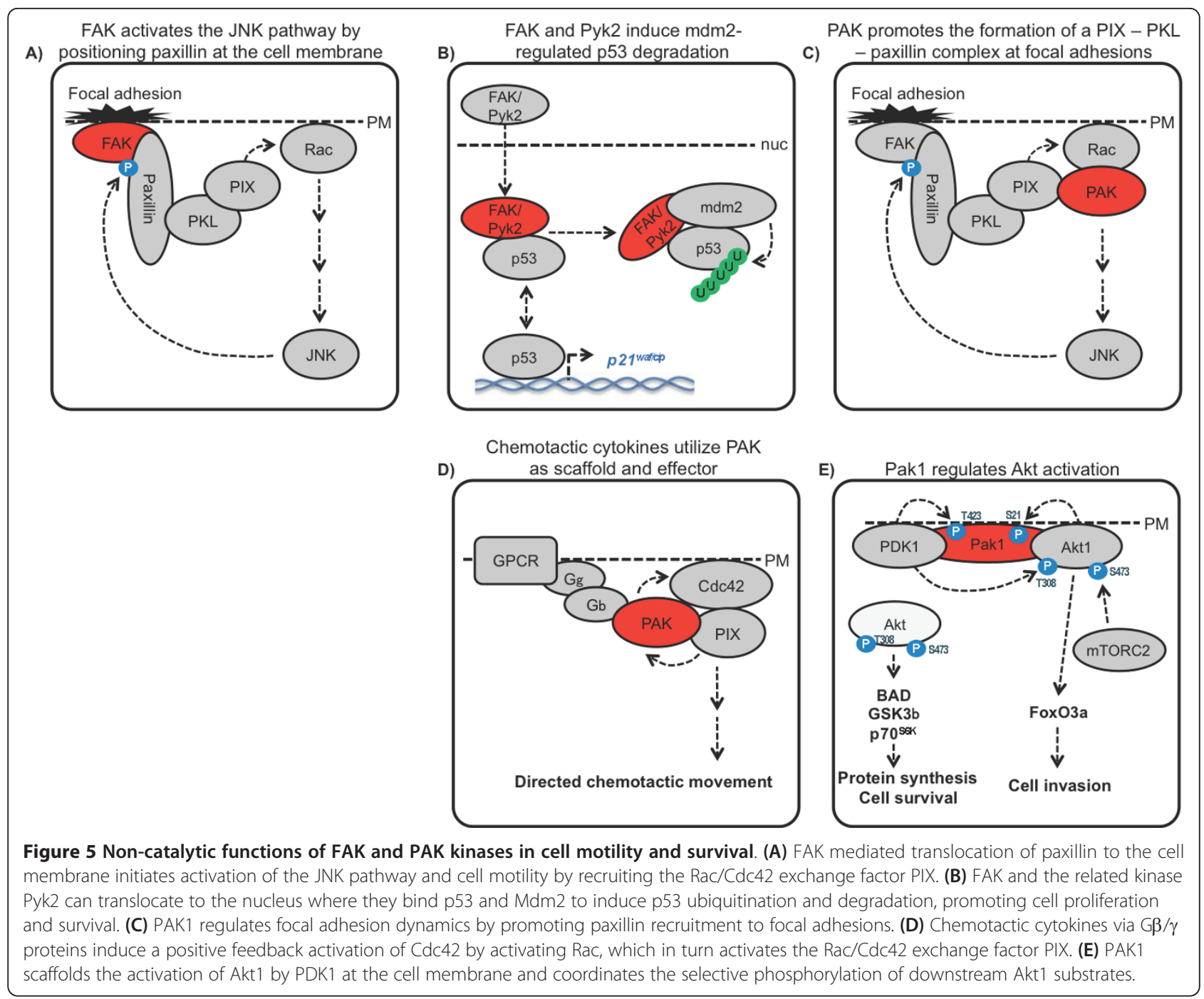

cytoskeletal regulation and motility, differentiation, carcinogenesis and tumor invasion [129-131]. Several early studies demonstrated that PAKs have some kinase-independent functions including cytoskeletal regulation and differentiation [132-134]. On the molecular level, PAK was demonstrated to coordinate the formation of a multi-protein complex, which contains PAK, PIX, PKL and Paxillin in focal adhesions (Figure 5C). This activity required the conformational change of PAK, since activated Rac or Cdc42 were able to promote this effect [135]. As described above, the scaffolding function of FAK seems instrumental for recruiting paxillin and activating Rac via PKL and PIX (Figure 5B). Active Rac binds PAK, which is not only a Rac effector but also interacts with PIX, which in turn stimulates Rac. Thus, multiple protein interactions coupled to positive feedback loops that promote protein recruitment may by key to focal adhesion formation and function by forming a temporally dynamic yet physically stable platform.
While these studies referred to a scaffolding function of the PAK N-terminal regulatory domain, later studies pointed out new, kinase-independent functions of the Cterminal PAK kinase domain [136,137]. A dual, kinasedependent and -independent role of PAK1 was demonstrated in myeloid cell migration. Chemokine binding to the G Protein Coupled Receptor (GPCR) induces a direct interaction between $G_{\beta \gamma}$ and PAK1. This interaction leads to activation of PIX and activation of Cdc42, which in turn leads to activation of PAK, an event required for the directional sensing of neutrophils [137]. The conformational change of PAK1 induced by the $G_{\beta \gamma}$ binding can prevent formation of PIX dimers, and therefore facilitate its GEF activity towards Cdc42 $[137,138]$. In this system, PAK1 mediates activation of its own catalytic activity, thus forming a positive feedback loop [137] (Figure 5D). In general, PAK1's ability to function as a scaffold for the GEFs that activates the GTPases, which activate PAK1, seems to generate an organising principle 
that enables cells to coordinate complex spatiotemporal responses. Similarly, PAK2 was recently described as regulating Cdc42-induced actin reorganization and spindle orientation by directly binding to the $\beta$-PIX GEF [139].

Another important PAK target is Akt, which has a central role in the regulation of metabolism, apoptosis, cell migration and transformation [140]. Whereas some studies suggest that PAK might directly phosphorylate Akt at the activating site S473 [141,142], a recent study demonstrates that PAK can also facilitate Akt phosphorylation in a kinase-independent manner [136] (Figure 5E). The kinase domain of PAK1 directly interacts with Akt and mediates its translocation to the plasma membrane, where S473 can be phosphorylated by mTORC2 [143] or PAK itself [141,142]. This step requires an activating conformational change of PAK induced by Rac binding, but no PAK kinase activity per se. PAK1 also recruits PDK1, the Akt T308 kinase [144], and this interaction is greatly facilitated by growth factors [136]. Thus, PAK1 promotes Akt translocation to the plasma membrane and serves as a scaffold that facilitates the interaction of PDK1 with Akt. Interestingly, PAK1mediated Akt activation exhibits isoform selectivity, affecting Akt1 responses more than Akt2, and in addition biased Akt substrate selection [136]. Expression of the N-terminal regulatory domain of PAK1, which seems to interfere with the ability of PAK to recruit PDK1, preferentially reduced the phosphorylation of nuclear Akt substrates, such as FoxO3a, while the phosphorylation levels of the cytosolic substrates S6K, BAD and GSK3 remained intact. This suggests that PAK scaffolding might direct the substrate specificity of Akt or limit its accessibility towards a subset of its substrates or both. It remains unclear, however, how the PAK dependent PDK1-Akt complex, which is formed at the cell membrane, affects nuclear Akt substrates. On the other hand, both Akt and PDK1 participate in PAK1 regulation. Akt can phosphorylate and partially activate PAK1 [145], and PDK1 was shown to activate PAK1 by direct phosphorylation in the activation loop [146]. Thus, kinases seem to be able to mutually activate each other in the PAK1 scaffolded PDK1-Akt complex by positive feedback loops, which is likely to result in a switchlike, digital signal output [147].

Members of the constitutively active group II PAK family (PAKs 4-6) also have been shown to mediate part of their effects via kinase-independent functions. PAK4 protects cells from apoptosis induced by death receptors in a kinase-independent manner by interfering with the recruitment and activation of caspase 8 to the death domains in the receptors [148]. In addition, PAK4 is needed for the efficient activation of survival pathways in response to TNF $\alpha$ by facilitating the binding of the scaffold protein TRADD to the activated TNF $\alpha$ receptor partly through a kinase-independent mechanism [149]. The role for PAK4 in regulating prosurvival pathways in a kinase-independent manner is a new function for this protein, and may help explaining its role in tumorigenesis $[150,151]$ and development [152].

\section{Kinase independent regulation of phosphoinositide signaling pathways \\ Phosphatidylinositol 3-kinases (PI3K)}

PI3Ks are intracellular lipid kinases that phosphorylate the 3'-hydroxyl group of phosphatidylinositol and phosphoinositides [153]. Their action is counteracted by the Phosphatase and tensin homolog (PTEN) phosphatase, which is frequently altered in cancer $[154,155]$. PI3Ks are divided into three classes according to their substrates specificity and sequence homology. Class I PI3Ks are activated by surface receptors and preferentially generate phosphatidylinositol-3,4,5-trisphosphate (PIP3) from phosphatidylinositol-4,5-bisphosphate (PI4,5P2) [153]. Class I PI3Ks are heterodimers consisting of a catalytic and a regulatory subunit. Catalytic domains $\mathrm{p} 110 \alpha, \mathrm{p} 110 \beta$ or $\mathrm{p} 110 \delta$ form together with p85, p55 or p50 regulatory domains class IA PI3Ks. Class I $\kappa$ B PI3K consists of the catalytic p110 $\gamma$ and regulatory $\mathrm{p} 101$ or $\mathrm{p} 84 / \mathrm{p} 87$ subunit $[153,156]$. Despite the fact that all class I PI3Ks generate PIP3, their simultaneous expression suggests that some of their functions might be not redundant. Indeed, a comprehensive study done by Knight and colleagues revealed specific functions of class PI3Ks in insulin signalling [157]. For instance, p110 $\beta$ is important for maintaining the PIP3 pool in unstimulated myotubes and balancing PTEN, a lipid phosphatase, activity thus setting a threshold for Akt activation. It is also required for Akt activation in a response to lysophosphatidic acid (LPA) stimulation [158-160]. However, p110 $\beta$ is dispensable for Akt activation induced by insulin, since p110 $\alpha$ is the major PIP2 kinase in this signalling pathway [157]. Surprisingly, in some cases the phenotype observed after catalytic subunit knockdown was much more severe than the phenotype induced by saturating concentrations of an isoform-specific chemical inhibitor [161,162]. This suggests the possibility that catalytic subunits of PI3 kinase might fulfil other, kinase independent functions in cellular regulation. These, kinase-independent functions of PI3Ks were elegantly validated by obtaining knock-in homozygote mice bearing kinase dead mutants of PI3 kinase. Importantly, the phenotype of these knock-in mice was markedly different and less severe than the corresponding knockout phenotypes [163]. Here, we discuss some specific examples of non-catalytic PI3 kinase functions.

$p 110 \beta$ p $110 \beta$ can be activated by growth factors and insulin. Several recent studies identified both kinasedependent and independent roles for this isoform [157-159]. p110 $\beta$ is dispensable for Akt phosphorylation induced by insulin, IGF-1 (Insulin-like Growth Factor), Epidermal Growth Factor (EGF) or Platelet-derived Growth Factor (PDGF) stimulation [158]. However, the 
catalytic activity of p110 $\beta$ is required for Akt activation mediated by lysophosphatidic acid (LPA) [158,159], and a lack of catalytically active $\mathrm{p} 110 \beta$ protected mice from breast cancer development induced by ERBB2 or from prostate tumour development driven by loss of PTEN $[158,159]$. The latter phenomenon can be attributed to a basal catalytic activity of $\mathrm{p} 110 \beta$ and its balancing effect towards PTEN activity [157]. On the other hand, kinaseindependent functions of $\mathrm{p} 110 \beta$ are crucial for several physiological processes, including embryonic development. Mice homozygotic for kinase-dead p110 $\beta$ develop normally and survive to adulthood, except growth retardation and developing a mild insulin resistance with age [158], whereas the p110 $\beta$ knockout leads to embryonic lethality in mice [164]. Further, catalytically inactive p110 $\beta$ facilitates endocytosis in a rate similar to the wild type $110 \beta$ subunit, as indicated by transferrin and EGFR uptake $[158,159] . p 110 \beta$, unlike p110 $\alpha$, can be found in the nucleus [165], and recent studies revealed kinasedependent and independent functions of $\mathrm{p} 110 \beta$ in DNA replication and repair $[161,162]$. In response to DNA double strand breaks (DSBs) PI3K $\beta$ participates in sensing the damage by mediating the binding of the DNA damage sensor protein Nbs1to DSBs and the recruitment of the full MRN (Mre11, Rad50, Nbs1) complex, which then activates the DNA damage kinase ATM. The assembly of this complex does not require PI3K $\beta$ catalytic activity, although kinase competent PI3K $\beta$ is more efficient [161]. ATM then recruits the replication protein A (RPA) complex and the ATR kinase. ATR and ATM are checkpoint kinases which halt the cell cycle until the DNA damage is repaired by the Rad51 recombinase (Figure 6A). The defective DNA repair in p110 $\beta$ knockout cells leads to genomic instability and chromosomal aberrations.
However, cells expressing kinase-dead p110 $\beta$ were predominantly normal, clearly demonstrating that kinase-independent functions of $\mathrm{p} 110 \beta$ are sufficient to upkeep radiation-induced DNA repair [161].

In DNA replication the catalytic activity of $p 110 \beta$ is required for the efficient progress of the replication fork [162]. p110 $\beta$ regulate PCNA (proliferating cell nuclear antigen) binding to the DNA and $\mathrm{p} 21^{\text {waf/cip }}$ phosphorylation. Surprisingly, the downregulation of $\mathrm{p} 110 \beta$ by shRNA revealed also kinase-independent function of p110 3 . p110 $\beta$ contributes to nuclear localization of Akt independently of its catalytic activity. In addition, the ability of p110 $\beta$ to bind PCNA and to facilitate its chromatin loading is at least partially independent of the $\mathrm{p} 110 \beta$ catalytic activity [162]. This study provides us with a molecular mechanism of $\mathrm{p} 110 \beta$ 's kinase-independent role in cell cycle previously demonstrated by BrdU incorporation assay [159].

$p 110 \gamma$ Unlike the ubiquitously expressed p110 $\alpha$ and p110 $\beta$ subunits, $p 110 \gamma$ expression is limited to certain tissues, including the hematopoietic system, endothelial cells, and cardiomyocytes [166,167].

Ischemia-induced angiogenesis is dependent on the PI3K $\gamma$ subunit. However, mice expressing a kinase-dead p110 $\gamma$ mutant entertain a normal reparative neovascularization, as indicated by capillary density and blood flow recovery. In detail, p110 $\gamma$ has a kinase-independent function in endothelial progenitor cells (EPC) migration induced by the chemokine Stromal-cell Derived Factor 1 (SDF-1), while EPC incorporation into vascular networks requires the catalytic activity of p110 [168].

Another study described the protective role of PI3K $\gamma$ in myocardial ischemia and reperfusion (M I/R) injury. PI3K $\gamma$ knockout mice had massive immediate and long-term
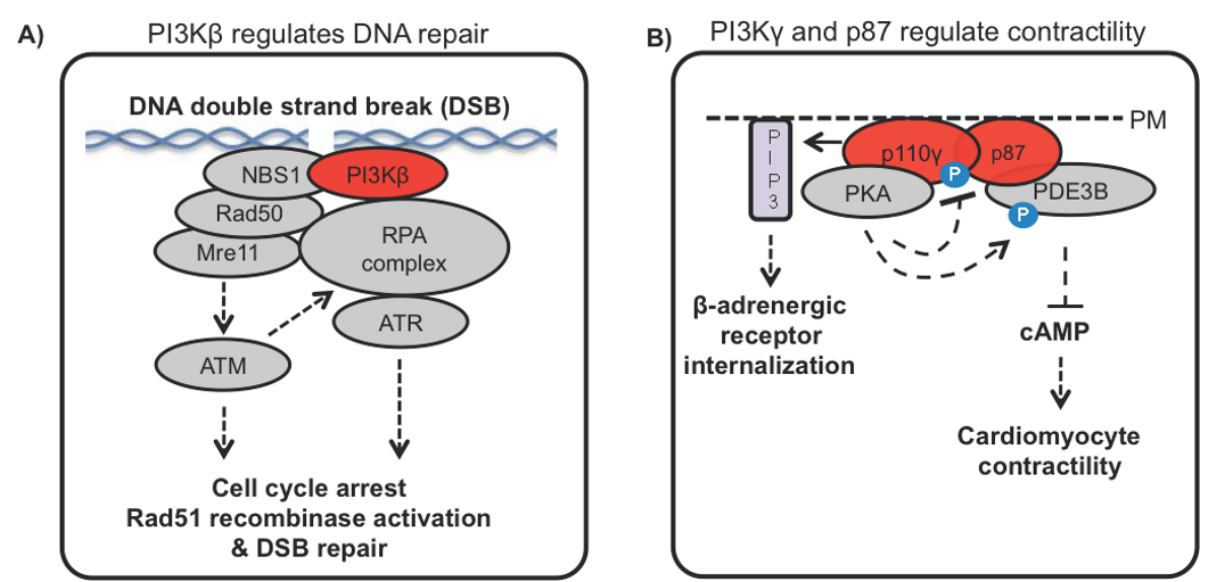

Figure 6 PI3K signaling independent of catalytic activity. (A) PI3K $\beta$ binding to DNA double strand breaks (DSBs) recruits DNA damage sensor and DNA repair enzymes. (B) PI3K $\gamma$ comprising of the $\mathrm{p} 110 \gamma$ and $\mathrm{p} 87$, catalytic and regulatory subunits, serves as scaffold for a Protein Kinase A (PKA) and phosphodiesterase 3B (PDE3B) containing protein complex that regulates $\beta$-adrenergic receptor internalization and muscle contractility in cardiomyocytes. 
heart damage induced by myocardial ischemia/reperfusion. The cardioprotective role of $\mathrm{p} 110 \gamma$ did not require its kinase activity, since catalytically inactive p110 $\gamma$ knock-in mice had phenotypes similar to their wild-type littermates [169].

Of interest, PI3K $\gamma$ knockout cardiomyocytes showed a higher contractility, and PI $3 \mathrm{~K} \gamma$ was shown to act as a negative regulator of contractility [170]. In cardiac hypertrophy models using chronic pressure overload caused by transverse aortic constriction (TAC) [171,172] PI3K $\gamma$ activity and expression levels were upregulated in the heart $[173,174]$. PI3K $\gamma$ knockout mice develop severe myocardial damage in response to TAC surgery suggesting that PI3K $\gamma$ has a protective role. Mice expressing kinase-dead PI3K $\gamma$ had preserved myocardial function a week after TAC, despite the lack of Akt and Erk activation in a response to TAC-induced mechanical stress. This can be explained by an ability of PI3K $\gamma$ to form a complex with phosphodiesterase 3B (PDE3B) independently of its kinase activity. $\mathrm{PDE} 3 \mathrm{~B}$ is associated with PI3K $\gamma$ in a constitutive manner and this interaction is required for PDE3B phosphodiesterase catalytic activity [174]. Furthermore, the PI3K regulatory subunit, p 87 but not p101 undergoes a physical interaction with PDE3B [175]. Thereby, PI3K $\gamma$ helps to maintain cAMP levels and thus prevents tissue necrosis independently of its kinase activity [174].

A subsequent study revealed the molecular mechanism of how cAMP levels in cardiomyocytes are regulated by PI3K independently of the PIP3 levels [176] (Figure 6B). While the regulatory subunit of PI3K, p87, directly binds phosphodiesterase 3B (PDE3B), the catalytic subunit, p110y, binds Protein Kinase A (PKA). cAMP, regenerated in cardiomyocytes upon B-adrenergic receptor stimulation, leads to activation of PKA. Catalytically active PKA phosphorylates and activates PDE3B, thus providing a negative feedback regulation. In this system, PI3K serves as an anchoring protein, bringing PKA in proximity to its substrate. In addition, PKA phosphorylates p110 and inhibits its kinase activity, thus decreasing the PIP3 levels. Since PIP3 is required for $\beta$-adrenergic receptor internalization, PKA helps to maintain receptor levels on the plasma membrane. In failing hearts, PI3K kinase activity is elevated, partially as a result of high expression levels of p110\%. In addition to that, the expression level of the regulatory subunit p101 is elevated as well. Since this subunit does not interact with PKA, the p110 $\gamma$ bound to p101 remains constitutively active leading to $\beta$-adrenergic receptor downregulation and heart failure [176].

\section{PDK1}

Phosphoinositide-Dependent Kinase 1 (PDK1) is a major regulator of at least 23 AGC kinases. Surprisingly, PDK1 is constitutively active and cell stimulation does not change its phosphorylation status at the activation loop or the kinase activity $[177,178]$. PDK1 mediates its own phosphorylation, thus explaining why the protein expressed in bacteria is phosphorylated and fully active; most likely this phosphorylation proceeds by a transmolecular mechanism [178]. In the PI3K signalling pathway PDK1 participates in Akt activation. Upon PIP3 accumulation mediated by PI3Ks Akt is recruited to the plasma membrane via its $\mathrm{PH}$ domain binding to PIP3 or by association with PAK1 as discussed above. PDK1then phosphorylates Akt at the activation loop (T308) $[177,178]$. PDK1 itself contains a PH domain, however it remains controversial whether cell stimulation affects its localization within the cell $[179,180]$.

Recent studies suggested that PDK1 has additional, kinase-independent functions in the coordination of signalling pathways $[181,182]$. For instance, PDK1 is involved in activating the small $\mathrm{G}$ protein $\mathrm{Ral}$ [182]. Ral is a small GTPase whose activation is mediated by a Ral specific GEF, Ral-GDS (Ral-Guanine nucleotide Dissociation Stimulator) [183]. Besides Raf kinases and PI3K, Ral-GDS is one of the three classic Ras effectors [184,185]. Ras contributes to Ral activation by bringing the Ral-GDS proximate to its substrate, but is not sufficient for the full catalytic activation of Ral-GDS [186]. Therefore, an additional step is required for optimal Ral activation, and PDK1 was demonstrated to fulfil this complementary role [182] (Figure 7A). PDK1 binds the $\mathrm{N}$-terminal region of RalGDS and relieves it from inhibition. This $\mathrm{N}$-terminal part of Ral-GDS was shown to possess autoinhibitory activity and Ral-GDS lacking this region has higher basal GEF activity. This function of PDK1 is kinase-independent, since a kinase-dead PDK1 mutant performed indistinguishably from wild type PDK1. Moreover, PDK1 lacking 50 amino acids in its regulatory domain did not enhance Ral-GDS activity, but was able to phosphorylate Akt at T308. These results demonstrate a clear distinction between kinase-dependent and -independent functions of PDK1 in response to growth factor stimulation [182].

Another example of PDK1 acting as a scaffolding protein was described in T-cells, where PDK1 takes part in NF $\kappa \mathrm{B}$ activation upon T-cell receptor (TCR) activation. PDK1 phosphorylates and recruits PKC $\theta$ to the plasma membrane and also recruits the CARMA1- Bcl10 -MALT1 complex, bringing it proximal to the $\mathrm{PKC} \theta$-bound $\mathrm{I} \kappa \mathrm{B}$ kinase (IKK) complex, which consists of two kinases IKK $\alpha$ / $\beta$ and a scaffolding protein IKK $\gamma$ or NEMO. The MALT1 complex ubiquitinates NEMO leading to the activation of $\mathrm{IKK} \alpha / \beta$ and phosphorylation of $\mathrm{I} \kappa \mathrm{B}$. Phosphorylation targets $\mathrm{I} \kappa \mathrm{B}$ for degradation thereby releasing $\mathrm{NF} \kappa \mathrm{B}$ to the nucleus where it activates the expression of survival and proliferation genes. Thus, PDK1, in addition of being the PKC $\theta$ kinase, also serves as a nucleating factor that assembles a multi-protein complex mediating $\mathrm{NF} \kappa \mathrm{B}$ activation downstream of TCR [181]. This multi-protein complex might also facilitate the PKC $\theta$-mediated phosphorylation of 


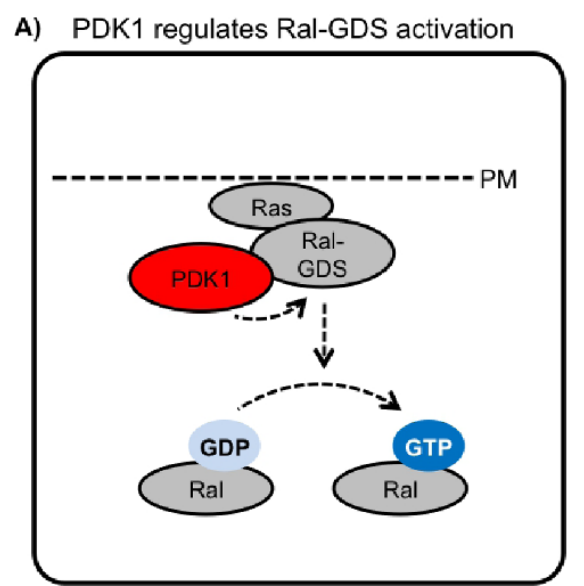

B) PDK1 regulates NFKB activation in T cells

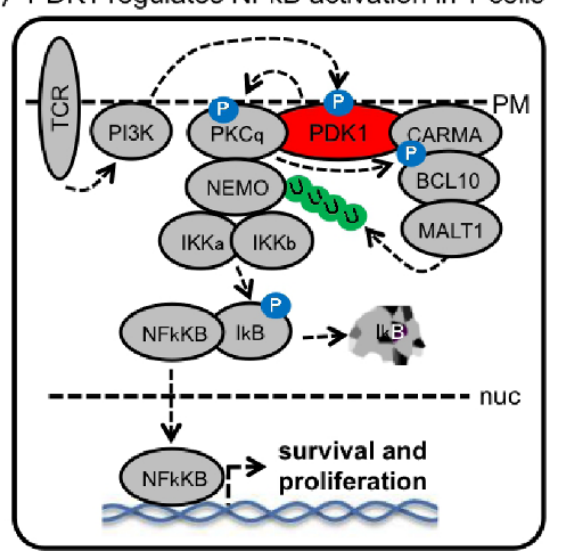

Figure 7 Catalytic-independent functions of PDK1. (A) PDK1 induces activation of the Ral small G protein by binding to and relieving its GEF Ral-GDS from the autoinhibitory conformation. (B) PDK1 mediates NFB activation in T-cells by serving as a scaffold that brings CARMA1-BCL10MALT1complex proximal to the PKCq-bound IKK complex, thus allowing ubiquitination of NEMO (IKK $\gamma$ ). This leads to activation of IKKS, phosphorylation and subsequent degradation of the $\mathrm{NF} \kappa \mathrm{B}$ inhibitor $\mid \kappa \mathrm{B}$ and release of active $\mathrm{NF} \kappa \mathrm{B}$ into the nucleus.

CARMA-1, which enhances the recruitment of BCL10MALT1. This event is absolutely required for TCRinduced NF $\kappa$ B activation [187]. Therefore, PDK1 fulfils a dual role operating both as a kinase and as a scaffolding protein that promotes formation of a multi-protein complex required for $\mathrm{NF} \kappa \mathrm{B}$ activation in T cells.

\section{Mammalian target of rapamycin ( $m T O R$ )}

mTOR kinase is found in two distinct multi-protein complexes with different substrate specificity, mTOR complex 1 (mTORC1) and mTORC2, that contain Raptor or Rictor as function defining elements, respectively. mTORC1 activation is mediated by Akt downstream to PI3K, whereas rather little is known about mTORC2 regulation [188]. The ability of mTORC1 to phosphorylate its downstream targets can be negatively regulated by rapamycin. It is unclear whether rapamycin affects mTOR kinase activity or prevents mTORC1 from interacting with its substrates, since rapamycin-bound mTOR complex 1 can still phosphorylate some of its substrates or autophosphorylate under certain conditions [189-191]. Therefore, the ability of rapamycin to block a particular signaling event does not indicate that this event necessarily requires the catalytic activity of mTORC1.

Rapamycin prevented the differentiation of $\mathrm{C} 2 \mathrm{C} 12$ mouse myoblast cells into skeletal muscle cells. This inhibition could be rescued by a rapamycin-resistant mTOR mutant [192]. Surprisingly, mTOR bearing an additional mutation that abolishes its kinase activity could also mediate cell differentiation. Of note, during cell differentiation the mTOR expression levels are upregulated on a posttranscriptional level, but no upregulation of mTOR kinase activity could be observed [192]. Another study performed in C2C12 cells demonstrated that mTOR mediated muscle cell differentiation did require its kinase activity [193]. The reason for this discrepancy is unclear.

However, subsequent studies, performed both in in vivo and in in vitro models, support the kinase independent function of mTOR in muscle cell differentiation and maintenance, and provide a molecular explanation. miRNA$125 \mathrm{~b}$ expressed in skeletal muscle cells negatively regulates muscle differentiation and injury-induced muscle regeneration by downregulating IGF-II, which is required for this process. mTOR negatively regulates miRNA-125b expression in repairing tissue, and that this mTOR function does not require its catalytic activity [194]. The conditional knockout of mTOR in muscle cells led to severe myopathy and premature death in mice. Among other changes induced by the mTOR knockout, cells lacking mTOR, but not raptor or rictor, had decreased expression levels of dystrophin. Dystrophin expression in muscle cells is regulated by mTOR on the transcriptional level independently of its kinase activity. Chromatin immunoprecipitation (ChIP) experiments indicated that mTOR binds to the dystrophin promoter [195]. Thus, this study indicates a kinase independent, but also raptor and rictor independent functions of mTOR in transcriptional regulation [195].

\section{Pseudokinases}

Interestingly, 48 out of the reported 518 kinases in the human genome seem to have lost their kinase activity altogether due to mutations of critical amino acids in their kinase domains thought to be required for catalytic functions. These so-called pseudokinases still have important catalysis-independent functions, e.g. as scaffolding proteins $[59,196]$. It is beyond the scope of this review to discuss the function of pseudokinases in detail, and we refer 
readers to recent reviews dedicated to this topic $[46,196,197]$. Within this review we only briefly discuss recent results indicating that the distinction between kinases and pseudokinases may be blurred. Pseudokinases seem to have developed from standard kinases by mutation of a few key catalytic residues while preserving the general primary and tertiary sequence organisation of the classic well-conserved kinase domains. Thus, the substrate binding properties of the kinase domains have evolved to become their main functions. This transition, however, seems to be gradual, and there is an increasing number of examples where pseudokinases can acquire kinase activity under certain conditions.

In the case of the Wnk kinase family, the general structural conservation of the kinase domain allows for a slightly modified catalytic mechanism despite lacking key catalytic residues characteristic for classic kinase domains [198-200]. Another example of a pseudokinase that uses an unconventional catalytic mechanism is the EGF receptor family member ErbB3/HER3. The traditional view was that ErbB3 lacks kinase activity but is phosphorylated and transactivated via dimerization with the active kinase ErbB2/HER2 [201,202]. Recent structural and molecular dynamics based modelling studies showed that the ErbB3 pseudokinase domain uses an alternative phosphotransfer mechanism to transautophosphorylate its intracellular region [203]. These recent results might suggest, that pseudokinases might be more active than anticipated by using alternative catalytic mechanisms.

Interestingly, in some cases these unorthodox catalytic activities may rely on very specific allosteric activation mechanisms exerted by the substrates and associated modulator proteins. A recent example is the scaffold KSR2, member of the extended Raf family and well known for its role in coordinating Raf-MEK-ERK complexes $[59,204]$, was shown to possess catalytic activity towards MEK [205]. This activity was dependent on Raf-1 binding to KSR2 and due to an allosteric activation mechanism. The KSR2 targeted phosphorylation sites in MEK were different from the known regulatory sites suggesting that the combination of a scaffold with the allosteric activation of a pseudokinase domain may confer exquisite substrate specificity. On the other hand, the observed KSR2 mediated MEK phosphorylation was of very low stoichiometry and its physiological relevance remains to be tested.

\section{Technical notes}

Most kinases mentioned in this review were first identified as enzymes, and only later additional functional functions were identified. Whereas the catalytic activity of a kinase is relatively easy to test, assaying for kinase-independent functions is more far more difficult. It still is challenging to determine kinase-interacting partners, and more importantly whether these protein-protein interactions contribute to the regulation of signalling independently of catalytic activity. In many studies kinase mutants lacking a kinase domain or bearing kinase-inactivating mutations were overexpressed, and the phenotype obtained was attributed to a non-catalytic activity of the protein. These studies contributed much to our current understanding of kinase activities in different systems. However, the massive overexpression of a mutated protein will change the stoichiometric ratios between interacting proteins and hence may not accurately reflect physiological phenomena. Novel technologies, such as small interfering RNA or knockin mice, allow creating a clean temporary or permanent background where the contribution of any particular kinase can be assessed without overexpression. In this case, the rescue of a phenotype with a kinase-dead kinase can serve as a much more reliable indication of non-catalytic kinase activities.

\section{Conclusions}

One of the clear functions of kinases within signalling networks is to receive signals from an upstream regulator and to amplify it by phosphorylating multiple substrate molecules. Any function independent of catalytic activity will be governed by purely stoichiometric relationships and will be lacking the amplification potential. However, while losing the advantage of signal amplification this mechanism might offer other advantages. Therefore, it is legitimate to ask: Why do protein kinases have non-catalytic functions? There are likely many more phosphorylation sites than proteins [206,207] not only raising questions about the functional roles of these phosphorylations, but also about the specificity of protein kinases. In fact, the specificity of protein kinases seems so poor that the expansion of tyrosine kinases went hand in hand with a reduction of the number of tyrosines in proteins [208]. Thus, is it the quest for specificity rather than catalytic efficiency that rules the kinase world? The first call on specificity is the kinase domain itself and the range of substrates it can interact with. The protein kinases that essentially consist of a kinase domain only, such as MAPKs, usually feature a large number of substrates and a large number of scaffolding proteins that direct them to selected substrates. In addition, their substrates have developed dedicated docking domains [82]. In contrast, large kinases with a complex domain structure, such as the PI3Ks are often remarkably specific, and usually function as scaffolds themselves. A crucial finding was the existence of SH2 and SH3 interaction domains by Tony Pawson's group. Many kinases described above contain multiple such protein-protein interaction domains, which are crucial for both, catalytic and non-catalytic, functions enabling them to act as scaffolds in addition to their catalytic role $[209,210]$. 
A variation on this theme is the competition for protein interactions, which can regulate the dynamic turnover of protein complexes. Although an oversimplification, this observation indicates that specificity is mainly achieved by regulating protein interactions that determine the binding of activators and substrates, subcellular localisation and dynamic changes of these conditions. In fact, manipulating protein docking interactions can override the intrinsic catalytic specificity of kinases [211]. Therefore, non-catalytic functions may be paramount to ensure the catalytic specificity of protein kinases. Many of the examples discussed above support this view. Often the cooperation between catalytic and non-catalytic kinase functions is needed to cause the full and correct biological effects. This design also affords maximum versatility by embedding protein kinases into different protein complexes in order to generate different signalling specificities. Pseudokinases may represent the extreme end of this scale. They lack catalytic activity altogether or only exhibit it under highly confined conditions depending on allosteric activation by binding partners [197].

These mechanisms contribute to the specificity of protein kinase action by providing mechanisms of a priori substrate discrimination. However, another and complementary way to achieve specificity is to increase the signal to noise ratio of protein kinase signalling. Again, non-catalytic functions seem to be key. An example is provided by the observation that tyrosine kinases often use $\mathrm{SH} 2$ domains, which dock to phospho-tyrosines, to recognise substrates previously phosphorylated by themselves or other tyrosine kinases [212]. Many of the signalling complexes discussed above are assembled via non-catalytic kinase functions, but involve multiple positive feedback loops exerted by phosphorylation. The combination of non-catalytic protein complex assembly and catalytic reinforcement of connections or outputs generate a high fidelity filter [147] that can program reliable biological responses.

\section{Acknowledgements}

This work was supported by the Science Foundation Ireland under Grant No. 06/CE/B1129. We apologise to the authors whose works could not be cited due to space constraints.

\section{Author details}

'Systems Biology Ireland, University College Dublin, Belfield, Dublin 4, Ireland. ${ }^{2}$ Conway Institute, University College Dublin, Belfield, Dublin 4, Ireland.

\section{Authors' contributions}

$J R, N V, D R$ and WK contributed to the preparation of the manuscript and approval of its final version.

\section{Competing interests}

The authors declare that they have no competing interests.

Received: 24 August 2011 Accepted: 28 October 2011

Published: 28 October 2011
References

1. Manning G, Plowman GD, Hunter T, Sudarsanam S: Evolution of protein kinase signaling from yeast to man. Trends in biochemical sciences 2002, 27:514-520.

2. Manning G: The Protein Kinase Complement of the Human Genome. Science (New York, NY) 2002, 298:1912-1934.

3. Deshmukh K, Anamika K, Srinivasan N: Evolution of domain combinations in protein kinases and its implications for functional diversity. Progress in biophysics and molecular biology 2010, 102:1-15.

4. Krebs EG, Fischer EH: The phosphorylase $b$ to a converting enzyme of rabbit skeletal muscle. Biochim Biophys Acta 1956, 20:150-157.

5. Krebs EG, Kent AB, Fischer $E H$ : The muscle phosphorylase $b$ kinase reaction. The Journal of biological chemistry 1958, 231:73-83.

6. Posas F, Saito $\mathrm{H}$ : Osmotic activation of the HOG MAPK pathway via Ste11p MAPKKK: scaffold role of Pbs2p MAPKK. Science 1997, 276:1702-1705

7. Madhani HD, Styles CA, Fink GR: MAP kinases with distinct inhibitory functions impart signaling specificity during yeast differentiation. Cell 1997, 91:673-684.

8. Robinson DR, Wu YM, Lin SF: The protein tyrosine kinase family of the human genome. Oncogene 2000, 19:5548-5557.

9. Zwick $E$, Bange J, Ullrich A: Receptor tyrosine kinase signalling as a target for cancer intervention strategies. Endocrine-related cancer 2001, 8:161-173.

10. Citri A, Yarden Y: EGF-ERBB signalling: towards the systems level. Nature reviews Molecular cell biology 2006, 7:505-516.

11. Yarden $Y$, Sliwkowski MX: Untangling the ErbB signalling network. Nature reviews Molecular cell biology 2001, 2:127-137.

12. Oda K, Matsuoka Y, Funahashi A, Kitano H: A comprehensive pathway map of epidermal growth factor receptor signaling. Molecular systems biology 2005, 1:2005 0010.

13. Zhang X, Gureasko J, Shen K, Cole PA, Kuriyan J: An allosteric mechanism for activation of the kinase domain of epidermal growth factor receptor. Cell 2006, 125:1137-1149.

14. Schulze WX, Deng L, Mann M: Phosphotyrosine interactome of the ErbBreceptor kinase family. Molecular systems biology 2005, 1:2005-2008.

15. Arteaga $\mathrm{CL}$ : Epidermal growth factor receptor dependence in human tumors: more than just expression? The oncologist 2002, 7(Suppl 4):31-39.

16. Weihua Z, Tsan R, Huang WC, Wu Q, Chiu CH, Fidler IJ, Hung MC: Survival of cancer cells is maintained by EGFR independent of its kinase activity. Cancer Cell 2008, 13:385-393.

17. Miettinen PJ, Berger JE, Meneses J, Phung Y, Pedersen RA, Werb Z, Derynck R: Epithelial immaturity and multiorgan failure in mice lacking epidermal growth factor receptor. Nature 1995, 376:337-341.

18. Luetteke NC, Phillips HK, Qiu TH, Copeland NG, Earp HS, Jenkins NA, Lee DC: The mouse waved- 2 phenotype results from a point mutation in the EGF receptor tyrosine kinase. Genes \& development 1994, 8:399-413.

19. Campos-Gonzalez R, Glenney JR Jr: Tyrosine phosphorylation of mitogenactivated protein kinase in cells with tyrosine kinase-negative epidermal growth factor receptors. The Journal of biological chemistry 1992, 267:14535-14538.

20. Coker KJ, Staros JV, Guyer CA: A kinase-negative epidermal growth factor receptor that retains the capacity to stimulate DNA synthesis. Proceedings of the National Academy of Sciences of the United States of America 1994, 91:6967-6971.

21. Selva E, Raden DL, Davis RJ: Mitogen-activated protein kinase stimulation by a tyrosine kinase-negative epidermal growth factor receptor. The Journal of biological chemistry 1993, 268:2250-2254.

22. Ewald JA, Coker KJ, Price JO, Staros JV, Guyer CA: Stimulation of mitogenic pathways through kinase-impaired mutants of the epidermal growth factor receptor. Experimental cell research 2001, 268:262-273.

23. Eldredge ER, Korf GM, Christensen TA, Connolly DC, Getz MJ, Maihle NJ: Activation of c-fos gene expression by a kinase-deficient epidermal growth factor receptor. Molecular and cellular biology 1994, 14:7527-7534.

24. Deb TB, Su L, Wong L, Bonvini E, Wells A, David M, Johnson GR: Epidermal growth factor (EGF) receptor kinase-independent signaling by EGF. J Biol Chem 2001, 276:15554-15560

25. Zhu H, Cao X, Ali-Osman F, Keir S, Lo HW: EGFR and EGFRvlll interact with PUMA to inhibit mitochondrial translocalization of PUMA and PUMAmediated apoptosis independent of EGFR kinase activity. Cancer Lett 2010, 294:101-110 
26. Wang Q, Villeneuve G, Wang Z: Control of epidermal growth factor receptor endocytosis by receptor dimerization, rather than receptor kinase activation. EMBO reports 2005, 6:942-948.

27. Hsu SC, Hung MC: Characterization of a novel tripartite nuclear localization sequence in the EGFR family. The Journal of biological chemistry 2007, 282:10432-10440.

28. Wang YN, Yamaguchi H, Hsu JM, Hung MC: Nuclear trafficking of the epidermal growth factor receptor family membrane proteins. Oncogene 2010, 29:3997-4006.

29. Liao HJ, Carpenter G: Role of the Sec61 translocon in EGF receptor trafficking to the nucleus and gene expression. Molecular biology of the cell 2007, 18:1064-1072.

30. Aqeilan RI, Donati V, Palamarchuk A, Trapasso F, Kaou M, Pekarsky Y, Sudol M, Croce CM: WW domain-containing proteins, WWOX and YAP, compete for interaction with ErbB-4 and modulate its transcriptional function. Cancer research 2005, 65:6764-6772.

31. Williams CC, Allison JG, Vidal GA, Burow ME, Beckman BS, Marrero L, Jones FE: The ERBB4/HER4 receptor tyrosine kinase regulates gene expression by functioning as a STAT5A nuclear chaperone. J Cell Biol 2004, 167:469-478

32. Komuro A, Nagai M, Navin NE, Sudol M: WW domain-containing protein YAP associates with ErbB-4 and acts as a co-transcriptional activator for the carboxyl-terminal fragment of ErbB-4 that translocates to the nucleus. The Journal of biological chemistry 2003, 278:33334-33341.

33. Deribe $Y L$, Wild P, Chandrashaker A, Curak J, Schmidt MH, Kalaidzidis Y, Milutinovic N, Kratchmarova I, Buerkle L, Fetchko MJ, et al: Regulation of epidermal growth factor receptor trafficking by lysine deacetylase HDAC6. Sci Signal 2009, 2:ra84.

34. Perrault $R$, Wright B, Storie B, Hatherell A, Zahradka P: Tyrosine kinaseindependent activation of extracellular-regulated kinase (ERK) $1 / 2$ by the insulin-like growth factor-1 receptor. Cellular signalling 2011, 23:739-746.

35. Keshet $Y$, Seger R: The MAP kinase signaling cascades: a system of hundreds of components regulates a diverse array of physiological functions. Methods Mol Biol 2010, 661:3-38.

36. von Kriegsheim A, Baiocchi D, Birtwistle M, Sumpton D, Bienvenut W, Morrice N, Yamada K, Lamond A, Kalna G, Orton R, et al: Cell fate decisions are specified by the dynamic ERK interactome. Nat Cell Biol 2009, 11:1458-1464.

37. Birtwistle MR, Kolch W: Biology using engineering tools: The negative feedback amplifier. Cell Cycle 2011, 10:2069-2076.

38. Ferrell JE Jr: Self-perpetuating states in signal transduction: positive feedback, double-negative feedback and bistability. Current opinion in cell biology 2002, 14:140-148.

39. Yoon $\mathrm{S}$, Seger R: The extracellular signal-regulated kinase: multiple substrates regulate diverse cellular functions. Growth Factors 2006, 24:21-44.

40. Marais R, Light $Y$, Paterson HF, Mason CS, Marshall CJ: Differential regulation of Raf-1, A-Raf, and B-Raf by oncogenic ras and tyrosine kinases. The Journal of biological chemistry 1997, 272:4378-4383.

41. Hindley A, Kolch W: Extracellular signal regulated kinase (ERK)/mitogen activated protein kinase (MAPK)-independent functions of Raf kinases. J Cell Sci 2002, 115:1575-1581.

42. Murakami MS, Morrison DK: Raf-1 without MEK? SCi STKE 2001, 2001:pe30.

43. Huser M, Luckett J, Chiloeches A, Mercer K, Iwobi M, Giblett S, Sun XM, Brown J, Marais R, Pritchard C: MEK kinase activity is not necessary for Raf-1 function. Embo J 2001, 20:1940-1951.

44. Mikula M, Schreiber M, Husak Z, Kucerova L, Ruth J, Wieser R, Zatloukal K, Beug H, Wagner EF, Baccarini M: Embryonic lethality and fetal liver apoptosis in mice lacking the c-raf-1 gene. Embo J 2001, 20:1952-1962.

45. Matallanas D, Birtwistle M, Romano D, Zebisch A, Rauch J, von Kriegsheim A, Kolch W: Raf Family Kinases: Old Dogs Have Learned New Tricks. Genes \& Cancer 2011, 2:232-260.

46. Udell CM, Rajakulendran T, Sicheri F, Therrien M: Mechanistic principles of RAF kinase signaling. Cell Mol Life Sci 2011, 68:553-565.

47. Wimmer R, Baccarini M: Partner exchange: protein-protein interactions in the Raf pathway. Trends Biochem Sci 2010, 35:660-668.

48. Weber CK, Slupsky JR, Kalmes HA, Rapp UR: Active Ras induces heterodimerization of cRaf and BRaf. Cancer Res 2001, 61:3595-3598.

49. Farrar MA, Alberol I, Perlmutter RM: Activation of the Raf-1 kinase cascade by coumermycin-induced dimerization. Nature 1996, 383:178-181.
50. Luo Z, Tzivion G, Belshaw PJ, Vavvas D, Marshall M, Avruch J: Oligomerization activates c-Raf-1 through a Ras-dependent mechanism. Nature 1996, 383:181-185.

51. Garnett MJ, Rana S, Paterson H, Barford D, Marais R: Wild-type and mutant B-RAF activate C-RAF through distinct mechanisms involving heterodimerization. Mol Cell 2005, 20:963-969.

52. Wan PT, Garnett MJ, Roe SM, Lee S, Niculescu-Duvaz D, Good VM, Jones CM, Marshall CJ, Springer CJ, Barford D, Marais R: Mechanism of activation of the RAF-ERK signaling pathway by oncogenic mutations of B-RAF. Cell 2004, 116:855-867.

53. Rushworth L, Hindley A, O'Neill E, Kolch W: Regulation and role of Raf-1/BRaf heterodimerization. Mol Cell Biol 2006, 26:2262-2272.

54. Rajakulendran T, Sahmi M, Lefrancois M, Sicheri F, Therrien M: A dimerization-dependent mechanism drives RAF catalytic activation. Nature 2009, 461:542-545.

55. Chadee DN, Xu D, Hung G, Andalibi A, Lim DJ, Luo Z, Gutmann DH Kyriakis JM: Mixed-lineage kinase 3 regulates B-Raf through maintenance of the B-Raf/Raf-1 complex and inhibition by the NF2 tumor suppressor protein. Proceedings of the National Academy of Sciences of the United States of America 2006, 103:4463-4468.

56. Yasuda S, Kai M, Imai S, Takeishi K, Taketomi A, Toyota M, Kanoh H, Sakane F: Diacylglycerol kinase eta augments C-Raf activity and B-Raf/CRaf heterodimerization. The Journal of biological chemistry 2009, 284:29559-29570.

57. Brennan DF, Dar AC, Hertz NT, Chao WC, Burlingame AL, Shokat KM Barford D: A Raf-induced allosteric transition of KSR stimulates phosphorylation of MEK. Nature 2011, 472:366-369.

58. Hu J, Yu H, Kornev AP, Zhao J, Filbert EL, Taylor SS, Shaw AS: Mutation that blocks ATP binding creates a pseudokinase stabilizing the scaffolding function of kinase suppressor of Ras, CRAF and BRAF. Proceedings of the National Academy of Sciences of the United States of America 2011, 108:6067-6072.

59. Kolch W: Coordinating ERK/MAPK signalling through scaffolds and inhibitors. Nat Rev Mol Cell Biol 2005, 6:827-837.

60. Bollag G, Hirth P, Tsai J, Zhang J, Ibrahim PN, Cho H, Spevak W, Zhang C, Zhang $Y$, Habets $G$, et al: Clinical efficacy of a RAF inhibitor needs broad target blockade in BRAF-mutant melanoma. Nature 2010, 467:596-599.

61. Flaherty KT, Puzanov I, Kim KB, Ribas A, McArthur GA, Sosman JA, O'Dwyer PJ, Lee RJ, Grippo JF, Nolop K, Chapman PB: Inhibition of mutated, activated BRAF in metastatic melanoma. N Engl J Med 2010, 363:809-819.

62. Cichowski K, Janne PA: Drug discovery: inhibitors that activate. Nature 2010, 464:358-359.

63. Amano M, Nakayama M, Kaibuchi K: Rho-kinase/ROCK: A key regulator of the cytoskeleton and cell polarity. Cytoskeleton (Hoboken) 2010, 67:545-554.

64. Piazzolla D, Meissl K, Kucerova L, Rubiolo C, Baccarini M: Raf-1 sets the threshold of Fas sensitivity by modulating Rok-a signaling. The Journal of Cell Biology 2005, 171:1013.

65. Ehrenreiter K, Piazzolla D, Velamoor V, Sobczak I, Small JV, Takeda J, Leung T, Baccarini M: Raf-1 regulates Rho signaling and cell migration. $J$ Cell Biol 2005, 168:955-964.

66. Niault T, Sobczak I, Meissl K, Weitsman G, Piazzolla D, Maurer G, Kern F, Ehrenreiter K, Hamerl M, Moarefi I, et al: From autoinhibition to inhibition in trans: the Raf- 1 regulatory domain inhibits Rok-alpha kinase activity. J Cell Biol 2009, 187:335-342.

67. Ehrenreiter K, Kern F, Velamoor V, Meissl K, Galabova-Kovacs G, Sibilia M, Baccarini M: Raf-1 addiction in ras-induced skin carcinogenesis. Cancer Cell 2009, 16:149-160.

68. O'Neill E, Rushworth L, Baccarini M, Kolch W: Role of the kinase MST2 in suppression of apoptosis by the proto-oncogene product Raf-1. Science 2004, 306:2267-2270

69. Matallanas D, Romano D, Yee K, Meissl K, Kucerova L, Piazzolla D, Baccarini M, Vass JK, Kolch W, O'Neill E: RASSF1A elicits apoptosis through an MST2 pathway directing proapoptotic transcription by the p73 tumor suppressor protein. Mol Cell 2007, 27:962-975.

70. O'Neill E, Kolch W: Taming the Hippo: Raf-1 controls apoptosis by suppressing MST2/Hippo. Cell Cycle 2005, 4:365-367.

71. Rauch J, O'Neill E, Mack B, Matthias C, Munz M, Kolch W, Gires O: Heterogeneous Nuclear Ribonucleoprotein H Blocks MST2-Mediated 
Apoptosis in Cancer Cells by Regulating a-raf Transcription. Cancer Res 2010, 70:1679-1688.

72. Rauch J, Moran-Jones K, Albrecht V, Schwarzl T, Hunter K, Gires O, Kolch W: c-Myc regulates RNA splicing of the A-Raf kinase and its activation of the ERK pathway. Cancer research 2011, 71:4664-4674.

73. Matsuzawa A, Ichijo H: Redox control of cell fate by MAP kinase: physiological roles of ASK1-MAP kinase pathway in stress signaling Biochim Biophys Acta 2008, 1780:1325-1336.

74. Chen J, Fujii K, Zhang L, Roberts T, Fu H: Raf-1 promotes cell survival by antagonizing apoptosis signal-regulating kinase 1 through a MEK-ERK independent mechanism. Proceedings of the National Academy of Sciences of the United States of America 2001, 98:7783-7788.

75. Yamaguchi O, Matsuzawa Chiharu Sadamitsu Hidenori Ichijo Manuela Baccarini Masatsugu Hori TWKNKKYHTTSHSHMAMTANITYMJ-iMKRCA, Otsu K: Cardiac-specific disruption of the c-raf-1 gene induces cardiac dysfunction and apoptosis. Journal of Clinical Investigation 2004, 114:937.

76. Yamamoto K, Ichijo H, Korsmeyer SJ: BCL-2 is phosphorylated and inactivated by an ASK1/Jun N-terminal protein kinase pathway normally activated at G(2)/M. Molecular and cellular biology 1999, 19:8469-8478

77. Noguchi K, Kokubu A, Kitanaka C, Ichijo H, Kuchino Y: ASK1-signaling promotes c-Myc protein stability during apoptosis. Biochemical and biophysical research communications 2001, 281:1313-1320.

78. Charette SJ, Lambert H, Landry J: A kinase-independent function of Ask1 in caspase-independent cell death. J Biol Chem 2001, 276:36071-36074.

79. Chang HY, Nishitoh H, Yang X, Ichijo H, Baltimore D: Activation of apoptosis signal-regulating kinase 1 (ASK1) by the adapter protein Daxx. Science 1998, 281:1860-1863.

80. Mochida Y, Takeda K, Saitoh M, Nishitoh H, Amagasa T, Ninomiya-Tsuji J, Matsumoto K, Ichijo H: ASK1 inhibits interleukin-1-induced NF-kappa B activity through disruption of TRAF6-TAK1 interaction. J Biol Chem 2000 275:32747-32752.

81. Tanoue T, Maeda R, Adachi M, Nishida E: Identification of a docking groove on ERK and p38 MAP kinases that regulates the specificity of docking interactions. The EMBO journal 2001, 20:466-479.

82. Tanoue T, Nishida E: Molecular recognitions in the MAP kinase cascades. Cellular signalling 2003, 15:455-462.

83. Yang SH, Whitmarsh AJ, Davis RJ, Sharrocks AD: Differential targeting of MAP kinases to the ETS-domain transcription factor Elk-1. The EMBO journal 1998, 17:1740-1749.

84. Shapiro PS, Whalen AM, Tolwinski NS, Wilsbacher J, Froelich-Ammon SJ, Garcia M, Osheroff N, Ahn NG: Extracellular Signal-Regulated Kinase Activates Topoisomerase llalpha through a Mechanism Independent of Phosphorylation. Molecular and cellular biology 1999, 19:3551.

85. Cohen-Armon M, Visochek L, Rozensal D, Kalal A, Geistrikh I, Klein R, Bendetz-Nezer S, Yao Z, Seger R: DNA-independent PARP-1 activation by phosphorylated ERK2 increases Elk1 activity: a link to histone acetylation. Molecular cell 2007, 25:297-308.

86. Camps M: Catalytic Activation of the Phosphatase MKP-3 by ERK2 Mitogen-Activated Protein Kinase. Science (New York, NY) 1998, 280:1262-1265.

87. Muda M, Boschert U, Dickinson R, Martinou JC, Martinou I, Camps M, Schlegel W, Arkinstall S: MKP-3, a novel cytosolic protein-tyrosine phosphatase that exemplifies a new class of mitogen-activated protein kinase phosphatase. The Journal of biological chemistry 1996, 271:4319-4326.

88. Nakakuki T, Birtwistle MR, Saeki Y, Yumoto N, Ide K, Nagashima T, Brusch L, Ogunnaike BA, Okada-Hatakeyama M, Kholodenko BN: Ligand-specific cFos expression emerges from the spatiotemporal control of ErbB network dynamics. Cell 2010, 141:884-896.

89. Hu S, Xie Z, Onishi A, Yu X, Jiang L, Lin J, Rho HS, Woodard C, Wang H, Jeong JS, et al: Profiling the human protein-DNA interactome reveals ERK2 as a transcriptional repressor of interferon signaling. Cell 2009, 139:610-622.

90. Meloche S, Pouyssegur J: The ERK1/2 mitogen-activated protein kinase pathway as a master regulator of the G1- to S-phase transition. Oncogene 2007, 26:3227-3239.

91. Rodríguez J, Calvo F, González JM, Casar B, Andrés V, Crespo P: ERK1/2 MAP kinases promote cell cycle entry by rapid, kinase-independent disruption of retinoblastoma-lamin A complexes. J Cell Biol 2010, 191:967-979.
92. Cuadrado A, Nebreda AR: Mechanisms and functions of p38 MAPK signalling. Biochem J 2010, 429:403-417.

93. Boldt S, Kolch W: Targeting MAPK signalling: Prometheus' fire or Pandora's box? Curr Pharm Des 2004, 10:1885-1905.

94. Kumar S, Boehm J, Lee JC: p38 MAP kinases: key signalling molecules as therapeutic targets for inflammatory diseases. Nat Rev Drug Discov 2003, 2:717-726.

95. Coulthard LR, White DE, Jones DL, McDermott MF, Burchill SA: p38(MAPK): stress responses from molecular mechanisms to therapeutics. Trends $\mathrm{Mol}$ Med 2009, 15:369-379.

96. Hui L, Bakiri L, Stepniak E, Wagner EF: p38alpha: a suppressor of cell proliferation and tumorigenesis. Cell Cycle 2007, 6:2429-2433.

97. Thornton TM, Rincon M: Non-classical p38 map kinase functions: cell cycle checkpoints and survival. Int J Biol Sci 2009, 5:44-51.

98. Fan L, Yang X, Du J, Marshall M, Blanchard K, Ye X: A novel role of p38 alpha MAPK in mitotic progression independent of its kinase activity. Cell Cycle 2005, 4:1616-1624.

99. Lim S, Zou Y, Friedman E: The transcriptional activator Mirk/Dyrk1B is sequestered by p38alpha/beta MAP kinase. J Biol Chem 2002, 277:49438-49445.

100. Parsons SJ, Parsons JT: Src family kinases, key regulators of signal transduction. Oncogene 2004, 23:7906-7909.

101. Boggon TJ, Eck MJ: Structure and regulation of Src family kinases. Oncogene 2004, 23:7918-7927.

102. Bromann PA, Korkaya H, Courtneidge SA: The interplay between Src family kinases and receptor tyrosine kinases. Oncogene 2004, 23:7957-7968.

103. Blume-Jensen P, Hunter T: Oncogenic kinase signalling. Nature 2001, 411:355-365.

104. Brown MT, Cooper JA: Regulation, substrates and functions of src. Biochim Biophys Acta Netherlands 1996, 1287:121-149.

105. Luo W, Slebos RJ, Hill S, Li M, Brabek J, Amanchy R, Chaerkady R, Pandey A, Ham AJ, Hanks SK: Global impact of oncogenic Src on a phosphotyrosine proteome. Journal of proteome research 2008, 7:3447-3460.

106. Schaller MD, Parsons JT: Focal adhesion kinase and associated proteins. Current opinion in cell biology 1994, 6:705-710.

107. Kaplan KB, Bibbins KB, Swedlow JR, Arnaud M, Morgan DO, Varmus HE: Association of the amino-terminal half of c-Src with focal adhesions alters their properties and is regulated by phosphorylation of tyrosine 527. EMBO J 1994, 13:4745-4756.

108. Schlaepfer DD, Hanks SK, Hunter T, van der Geer P: Integrin-mediated signal transduction linked to Ras pathway by GRB2 binding to focal adhesion kinase. Nature 1994, 372:786-791.

109. Kaplan KB, Swedlow JR, Morgan DO, Varmus HE: c-Src enhances the spreading of src-/- fibroblasts on fibronectin by a kinase-independent mechanism. Genes \& development 1995, 9:1505-1517.

110. Schlaepfer D, Broome M, Hunter T: Fibronectin-stimulated signaling from a focal adhesion kinase-c-Src complex: involvement of the Grb2, p130cas, and Nck adaptor proteins. Molecular and cellular biology 1997, 17:1702.

111. Brunton VG, Avizienyte E, Fincham VJ, Serrels B, Metcalf CA, Sawyer TK, Frame MC: Identification of Src-specific phosphorylation site on focal adhesion kinase: dissection of the role of $\mathrm{Src} \mathrm{SH} 2$ and catalytic functions and their consequences for tumor cell behavior. Cancer research 2005, 65:1335-1342.

112. Schwartzberg PL, Xing L, Hoffmann O, Lowell CA, Garrett L, Boyce BF, Varmus HE: Rescue of osteoclast function by transgenic expression of kinase-deficient Src in src-/- mutant mice. Genes Dev 1997, 11:2835-2844.

113. Garcia-Martinez JM, Calcabrini A, Gonzalez L, Martin-Forero E, AgulloOrtuno MT, Simon V, Watkin H, Anderson SM, Roche S, Martin-Perez J: A non-catalytic function of the Src family tyrosine kinases controls prolactin-induced Jak2 signaling. Cellular signalling 2010, 22:415-426.

114. Xu H, Littman DR: A kinase-independent function of Lck in potentiating antigen-specific T cell activation. Cell 1993, 74:633-643.

115. Katsuta H, Tsuji S, Niho Y, Kurosaki T, Kitamura D: Lyn-mediated downregulation of $B$ cell antigen receptor signaling: inhibition of protein kinase $C$ activation by Lyn in a kinase-independent fashion. J Immunol 1998, 160:1547-1551.

116. Frame MC, Patel H, Serrels B, Lietha D, Eck MJ: The FERM domain: organizing the structure and function of FAK. Nat Rev Mol Cell Biol 2010, 11:802-814. 
117. Schaller MD: Cellular functions of FAK kinases: insight into molecular mechanisms and novel functions. J Cell Sci 2010, 123:1007-1013.

118. Igishi T, Fukuhara S, Patel V, Katz BZ, Yamada KM, Gutkind JS: Divergent signaling pathways link focal adhesion kinase to mitogen-activated protein kinase cascades. Evidence for a role of paxillin in c-Jun $\mathrm{NH}(2)-$ terminal kinase activation. J Biol Chem 1999, 274:30738-30746.

119. Turner CE, Brown MC, Perrotta JA, Riedy MC, Nikolopoulos SN, McDonald AR, Bagrodia S, Thomas S, Leventhal PS: Paxillin LD4 motif binds PAK and PIX through a novel 95-kD ankyrin repeat, ARF-GAP protein: A role in cytoskeletal remodeling. J Cell Biol 1999, 145:851-863.

120. Coso OA, Chiariello M, Yu JC, Teramoto H, Crespo P, Xu N, Miki T, Gutkind JS: The small GTP-binding proteins Rac1 and $\mathrm{Cdc} 42$ regulate the activity of the JNK/SAPK signaling pathway. Cell 1995, 81:1137-1146.

121. Minden A, Lin A, Claret FX, Abo A, Karin M: Selective activation of the JNK signaling cascade and c-Jun transcriptional activity by the small GTPases Rac and Cdc42Hs. Cell 1995, 81:1147-1157.

122. Huang Z, Yan DP, Ge BX: JNK regulates cell migration through promotion of tyrosine phosphorylation of paxillin. Cellular signalling 2008, 20:2002-2012.

123. Shen TL, Park AY, Alcaraz A, Peng X, Jang I, Koni P, Flavell RA, Gu H, Guan JL: Conditional knockout of focal adhesion kinase in endothelial cells reveals its role in angiogenesis and vascular development in late embryogenesis. J Cell Biol 2005, 169:941-952.

124. Zhao X, Peng X, Sun S, Park AY, Guan JL: Role of kinase-independent and -dependent functions of FAK in endothelial cell survival and barrier function during embryonic development. J Cell Biol 2010, 189:955-965.

125. el-Deiry WS, Tokino T, Velculescu VE, Levy DB, Parsons R, Trent JM, Lin D, Mercer WE, Kinzler KW, Vogelstein B: WAF1, a potential mediator of p53 tumor suppression. Cell 1993, 75:817-825.

126. Lim ST, Chen XL, Lim Y, Hanson DA, Vo TT, Howerton K, Larocque N, Fisher SJ, Schlaepfer DD, llic D: Nuclear FAK promotes cell proliferation and survival through FERM-enhanced p53 degradation. Mol Cell 2008, 29:9-22.

127. Weis SM, Lim ST, Lutu-Fuga KM, Barnes LA, Chen XL, Gothert JR, Shen TL, Guan JL, Schlaepfer DD, Cheresh DA: Compensatory role for Pyk2 during angiogenesis in adult mice lacking endothelial cell FAK. J Cell Biol 2008, 181:43-50.

128. Lim ST, Miller NL, Nam JO, Chen XL, Lim Y, Schlaepfer DD: Pyk2 inhibition of $\mathrm{p} 53$ as an adaptive and intrinsic mechanism facilitating cell proliferation and survival. The Journal of biological chemistry 2010, 285:1743-1753.

129. Bokoch GM: Biology of the p21-activated kinases. Annu Rev Biochem 2003, 72:743-781.

130. Nikolic M: The Pak1 kinase: an important regulator of neuronal morphology and function in the developing forebrain. Mol Neurobiol 2008, 37:187-202.

131. Molli PR, Li DQ, Murray BW, Rayala SK, Kumar R: PAK signaling in oncogenesis. Oncogene 2009, 28:2545-2555.

132. Daniels RH, Hall PS, Bokoch GM: Membrane targeting of p21-activated kinase 1 (PAK1) induces neurite outgrowth from PC12 cells. Embo J 1998, 17:754-764.

133. Frost JA, Khokhlatchev A, Stippec S, White MA, Cobb MH: Differential effects of PAK1-activating mutations reveal activity-dependent and -independent effects on cytoskeletal regulation. J Biol Chem 1998, 273:28191-28198.

134. Sells MA, Knaus UG, Bagrodia S, Ambrose DM, Bokoch GM, Chernoff Human p21-activated kinase (Pak1) regulates actin organization in mammalian cells. Curr Biol 1997, 7:202-210.

135. Brown MC, West KA, Turner CE: Paxillin-dependent paxillin kinase linker and p21-activated kinase localization to focal adhesions involves a multistep activation pathway. Mol Biol Cell 2002, 13:1550-1565.

136. Higuchi M, Onishi K, Kikuchi C, Gotoh Y: Scaffolding function of PAK in the PDK1-Akt pathway. Nat Cell Biol 2008, 10:1356-1364.

137. Li Z, Hannigan M, Mo Z, Liu B, Lu W, Wu Y, Smrcka AV, Wu G, Li L, Liu M, et al: Directional sensing requires $\mathrm{G}$ beta gamma-mediated PAK1 and PIX alpha-dependent activation of Cdc42. Cell 2003, 114:215-227.

138. Feng Q, Baird D, Cerione RA: Novel regulatory mechanisms for the Dbl family guanine nucleotide exchange factor Cool-2/alpha-Pix. Embo J 2004, 23:3492-3504.

139. Mitsushima M, Toyoshima F, Nishida E: Dual role of Cdc42 in spindle orientation control of adherent cells. Mol Cell Biol 2009, 29:2816-2827.
140. Fayard E, Xue G, Parcellier A, Bozulic L, Hemmings BA: Protein kinase B (PKB/Akt), a key mediator of the PI3K signaling pathway. Curr Top Microbiol Immunol 2010, 346:31-56.

141. Gorlach A, BelAiba RS, Hess J, Kietzmann T: Thrombin activates the p21activated kinase in pulmonary artery smooth muscle cells. Role in tissue factor expression. Thromb Haemost 2005, 93:1168-1175.

142. Mao K, Kobayashi S, Jaffer ZM, Huang Y, Volden P, Chernoff J, Liang Q: Regulation of Akt/PKB activity by P21-activated kinase in cardiomyocytes. J Mol Cell Cardiol 2008, 44:429-434.

143. Sarbassov DD, Guertin DA, Ali SM, Sabatini DM: Phosphorylation and regulation of Akt/PKB by the rictor-mTOR complex. Science 2005, 307:1098-1101

144. Alessi DR, James SR, Downes CP, Holmes AB, Gaffney PR, Reese CB, Cohen P: Characterization of a 3-phosphoinositide-dependent protein kinase which phosphorylates and activates protein kinase Balpha. Curr Biol 1997, 7:261-269.

145. Zhou GL, Zhuo Y, King CC, Fryer BH, Bokoch GM, Field J: Akt phosphorylation of serine 21 on Pak1 modulates Nck binding and cell migration. Mol Cell Biol 2003, 23:8058-8069.

146. King CC, Gardiner EM, Zenke FT, Bohl BP, Newton AC, Hemmings BA, Bokoch GM: p21-activated kinase (PAK1) is phosphorylated and activated by 3-phosphoinositide-dependent kinase-1 (PDK1).J Biol Chem 2000, 275:41201-41209.

147. Kholodenko BN: Cell-signalling dynamics in time and space. Nat Rev Mol Cell Biol 2006, 7:165-176.

148. Gnesutta N, Minden A: Death receptor-induced activation of initiator caspase 8 is antagonized by serine/threonine kinase PAK4. Mol Cell Biol 2003, 23:7838-7848.

149. Li X, Minden A: PAK4 functions in tumor necrosis factor (TNF) alphainduced survival pathways by facilitating TRADD binding to the TNF receptor. J Biol Chem 2005, 280:41192-41200.

150. Liu Y, Chen N, Cui X, Zheng X, Deng L, Price S, Karantza V, Minden A: The protein kinase Pak4 disrupts mammary acinar architecture and promotes mammary tumorigenesis. Oncogene 2010, 29:5883-5894.

151. Siu MK, Chan HY, Kong DS, Wong ES, Wong OG, Ngan HY, Tam KF, Zhang $\mathrm{H}$, Li Z, Chan QK, et al: p21-activated kinase 4 regulates ovarian cancer cell proliferation, migration, and invasion and contributes to poor prognosis in patients. Proceedings of the National Academy of Sciences of the United States of America 2010, 107:18622-18627.

152. Qu J, Li X, Novitch BG, Zheng Y, Kohn M, Xie JM, Kozinn S, Bronson R, Beg AA, Minden A: PAK4 kinase is essential for embryonic viability and for proper neuronal development. Molecular and cellular biology 2003, 23:7122-7133.

153. Engelman JA, Luo J, Cantley LC: The evolution of phosphatidylinositol 3kinases as regulators of growth and metabolism. Nat Rev Genet 2006, 7:606-619.

154. Leslie NR, Batty IH, Maccario H, Davidson L, Downes CP: Understanding PTEN regulation: PIP2, polarity and protein stability. Oncogene 2008 , 27:5464-5476.

155. Restuccia DF, Hemmings BA: From man to mouse and back again: advances in defining tumor AKTivities in vivo. Dis Model Mech 2010 3:705-720.

156. Liu P, Cheng H, Roberts TM, Zhao JJ: Targeting the phosphoinositide 3kinase pathway in cancer. Nat Rev Drug Discov 2009, 8:627-644.

157. Knight ZA, Gonzalez B, Feldman ME, Zunder ER, Goldenberg DD, Williams O, Loewith R, Stokoe D, Balla A, Toth B, et al: A pharmacological map of the PI3-K family defines a role for p110alpha in insulin signaling. Cell 2006, 125:733-747.

158. Ciraolo E, lezzi M, Marone R, Marengo S, Curcio C, Costa C, Azzolino O, Gonella C, Rubinetto C, Wu H, et al: Phosphoinositide 3-kinase p110beta activity: key role in metabolism and mammary gland cancer but not development. Sci Signal 2008, 1:ra3.

159. Jia S, Liu Z, Zhang S, Liu P, Zhang L, Lee SH, Zhang J, Signoretti S, Loda M, Roberts TM, Zhao JJ: Essential roles of PI(3)K-p110beta in cell growth, metabolism and tumorigenesis. Nature 2008, 454:776-779.

160. Yart A, Roche S, Wetzker R, Laffargue M, Tonks N, Mayeux P, Chap H, Raynal P: A function for phosphoinositide 3-kinase beta lipid products in coupling beta gamma to Ras activation in response to lysophosphatidic acid. J Biol Chem 2002, 277:21167-21178.

161. Kumar A, Fernandez-Capetillo O, Carrera AC: Nuclear phosphoinositide 3kinase beta controls double-strand break DNA repair. Proc Natl Acad SCi USA 2010, 107:7491-7496. 
162. Marques M, Kumar A, Poveda AM, Zuluaga S, Hernandez C, Jackson S, Pasero P, Carrera AC: Specific function of phosphoinositide 3-kinase beta in the control of DNA replication. Proc Natl Acad Sci USA 2009, 106:7525-7530.

163. Hirsch E, Braccini L, Ciraolo E, Morello F, Perino A: Twice upon a time: PI3K's secret double life exposed. Trends Biochem Sci 2009, 34:244-248.

164. Bi L, Okabe I, Bernard DJ, Nussbaum RL: Early embryonic lethality in mice deficient in the p110beta catalytic subunit of PI 3-kinase. Mamm Genome 2002, 13:169-172.

165. Marques M, Kumar A, Cortes I, Gonzalez-Garcia A, Hernandez C, MorenoOrtiz MC, Carrera AC: Phosphoinositide 3-kinases p110alpha and p110beta regulate cell cycle entry, exhibiting distinct activation kinetics in G1 phase. Mol Cell Biol 2008, 28:2803-2814.

166. Perino A, Ghigo A, Damilano F, Hirsch E: Identification of the macromolecular complex responsible for PI3Kgamma-dependent regulation of cAMP levels. Biochem Soc Trans 2006, 34:502-503.

167. Rommel C, Camps M, Ji H: PI3K delta and PI3K gamma: partners in crime in inflammation in rheumatoid arthritis and beyond? Nat Rev Immunol 2007, 7:191-201.

168. Madeddu P, Kraenkel N, Barcelos LS, Siragusa M, Campagnolo P, Oikawa A, Caporali A, Herman A, Azzolino O, Barberis L, et al: Phosphoinositide 3kinase gamma gene knockout impairs postischemic neovascularization and endothelial progenitor cell functions. Arterioscler Thromb Vasc Biol 2008, 28:68-76.

169. Haubner BJ, Neely GG, VoelkI JG, Damilano F, Kuba K, Imai Y, Komnenovic V, Mayr A, Pachinger O, Hirsch E, et al: Pl3Kgamma protects from myocardial ischemia and reperfusion injury through a kinaseindependent pathway. PLOS ONE 2010, 5:e9350.

170. Crackower MA, Oudit GY, Kozieradzki I, Sarao R, Sun H, Sasaki T, Hirsch E, Suzuki A, Shioi T, Irie-Sasaki J, et al: Regulation of myocardial contractility and cell size by distinct PI3K-PTEN signaling pathways. Cell 2002, 110:737-749.

171. Rockman HA, Ross RS, Harris AN, Knowlton KU, Steinhelper ME, Field LJ, Ross J, Chien KR: Segregation of atrial-specific and inducible expression of an atrial natriuretic factor transgene in an in vivo murine model of cardiac hypertrophy. Proc Natl Acad Sci USA 1991, 88:8277-8281.

172. Tarnavski O: Mouse surgical models in cardiovascular research. Methods Mol Biol 2009, 573:115-137.

173. Naga Prasad SV, Laporte SA, Chamberlain D, Caron MG, Barak L, Rockman HA: Phosphoinositide 3-kinase regulates beta2-adrenergic receptor endocytosis by AP-2 recruitment to the receptor/beta-arrestin complex. J Cell Biol 2002, 158:563-575.

174. Patrucco E, Notte A, Barberis L, Selvetella G, Maffei A, Brancaccio M, Marengo S, Russo G, Azzolino O, Rybalkin SD, et al: PI3Kgamma modulates the cardiac response to chronic pressure overload by distinct kinasedependent and -independent effects. Cell 2004, 118:375-387.

175. Voigt $P$, Dorner MB, Schaefer M: Characterization of p87PIKAP, a novel regulatory subunit of phosphoinositide 3-kinase gamma that is highly expressed in heart and interacts with PDE3B. J Biol Chem 2006, 281:9977-9986.

176. Perino A, Ghigo A, Ferrero E, Morello F, Santulli G, Baillie GS, Damilano F, Dunlop AJ, Pawson C, Walser R, et al: Integrating cardiac PIP3 and CAMP signaling through a PKA anchoring function of p110gamma. Mol Cell 2011, 42:84-95.

177. Bayascas JR: Dissecting the role of the 3-phosphoinositide-dependent protein kinase-1 (PDK1) signalling pathways. Cell Cycle 2008, 7:2978-2982.

178. Mora A, Komander D, van Aalten DM, Alessi DR: PDK1, the master regulator of AGC kinase signal transduction. Semin Cell Dev Biol 2004, 15:161-170.

179. Anderson KE, Coadwell J, Stephens LR, Hawkins PT: Translocation of PDK-1 to the plasma membrane is important in allowing PDK-1 to activate protein kinase B. Curr Biol 1998, 8:684-691.

180. Currie RA, Walker KS, Gray A, Deak M, Casamayor A, Downes CP, Cohen P, Alessi DR, Lucocq J: Role of phosphatidylinositol 3,4,5-trisphosphate in regulating the activity and localization of 3-phosphoinositide-dependent protein kinase-1. Biochem J 1999, 337(Pt 3):575-583.

181. Lee KY, D'Acquisto F, Hayden MS, Shim JH, Ghosh S: PDK1 nucleates T cell receptor-induced signaling complex for NF-kappaB activation. Science 2005, 308:114-118.

182. Tian X, Rusanescu G, Hou W, Schaffhausen B, Feig LA: PDK1 mediates growth factor-induced Ral-GEF activation by a kinase-independent mechanism. Embo J 2002, 21:1327-1338.
183. Albright CF, Giddings BW, Liu J, Vito M, Weinberg RA: Characterization of a guanine nucleotide dissociation stimulator for a ras-related GTPase. Embo J 1993, 12:339-347.

184. Karnoub AE, Weinberg RA: Ras oncogenes: split personalities. Nat Rev Mol Cell Biol 2008, 9:517-531.

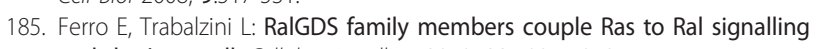
and that's not all. Cellular signalling 2010, 22:1804-1810.

186. Rusanescu G, Gotoh T, Tian X, Feig LA: Regulation of Ras signaling specificity by protein kinase C. Mol Cell Biol 2001, 21:2650-2658.

187. Matsumoto R, Wang D, Blonska M, Li H, Kobayashi M, Pappu B, Chen Y, Lin X: Phosphorylation of CARMA1 plays a critical role in T Cell receptormediated NF-kappaB activation. Immunity 2005, 23:575-585.

188. Zoncu R, Efeyan A, Sabatini DM: mTOR: from growth signal integration to cancer, diabetes and ageing. Nat Rev Mol Cell Biol 2011, 12:21-35.

189. Gingras AC, Raught B, Sonenberg N: Regulation of translation initiation by FRAP/mTOR. Genes Dev 2001, 15:807-826.

190. Thoreen CC, Kang SA, Chang JW, Liu Q, Zhang J, Gao Y, Reichling L, Sim T, Sabatini DM, Gray NS: An ATP-competitive mammalian target of rapamycin inhibitor reveals rapamycin-resistant functions of mTORC1. $J$ Biol Chem 2009, 284:8023-8032.

191. Feldman ME, Apsel B, Uotila A, Loewith R, Knight ZA, Ruggero D, Shokat KM: Active-site inhibitors of mTOR target rapamycin-resistant outputs of mTORC1 and mTORC2. PLOS Biol 2009, 7:e38.

192. Erbay $E_{1}$ Chen J: The mammalian target of rapamycin regulates $\mathrm{C} 2 \mathrm{C} 12$ myogenesis via a kinase-independent mechanism. J Biol Chem 2001, 276:36079-36082.

193. Shu L, Zhang X, Houghton PJ: Myogenic differentiation is dependent on both the kinase function and the $\mathrm{N}$-terminal sequence of mammalian target of rapamycin. J Biol Chem 2002, 277:16726-16732.

194. Ge Y, Sun Y, Chen J: IGF-II is regulated by microRNA-125b in skeletal myogenesis. J Cell Biol 2011, 192:69-81.

195. Risson V, Mazelin L, Roceri M, Sanchez H, Moncollin V, Corneloup C, Richard-Bulteau H, Vignaud A, Baas D, Defour A, et al: Muscle inactivation of mTOR causes metabolic and dystrophin defects leading to severe myopathy. J Cell Biol 2009, 187:859-874.

196. Boudeau J, Miranda-Saavedra D, Barton GJ, Alessi DR: Emerging roles of pseudokinases. Trends Cell Biol 2006, 16:443-452.

197. Zeqiraj $E$, van Aalten DM: Pseudokinases-remnants of evolution or key allosteric regulators? Curr Opin Struct Biol 2010, 20:772-781.

198. Xu Be: WNK1, a Novel Mammalian Serine/Threonine Protein Kinase Lacking the Catalytic Lysine in Subdomain II. Journal of Biological Chemistry 2000, 275:16795-16801.

199. Xu B-e, Lee B-H, Min X, Lenertz L, Heise CJ, Stippec S, Goldsmith EJ, Cobb MH: WNK1: analysis of protein kinase structure, downstream targets, and potential roles in hypertension. Cell Res 2005, 15:6-10.

200. Xu BE, Stippec S, Lazrak A, Huang CL, Cobb MH: WNK1 activates SGK1 by a phosphatidylinositol 3-kinase-dependent and non-catalytic mechanism. The Journal of biological chemistry 2005, 280:34218-34223.

201. Holbro T, Beerli RR, Maurer F, Koziczak M, Barbas CF, Hynes NE: The ErbB2/ ErbB3 heterodimer functions as an oncogenic unit: ErbB2 requires ErbB3 to drive breast tumor cell proliferation. Proceedings of the National Academy of Sciences of the United States of America 2003, 100:8933-8938.

202. Berger MB, Mendrola JM, Lemmon MA: ErbB3/HER3 does not homodimerize upon neuregulin binding at the cell surface. FEBS letters 2004, 569:332-336.

203. Shi F, Telesco SE, Liu Y, Radhakrishnan R, Lemmon MA: ErbB3/HER3 intracellular domain is competent to bind ATP and catalyze autophosphorylation. Proceedings of the National Academy of Sciences of the United States of America 2010, 107:7692-7697.

204. Brown MD, Sacks DB: Protein scaffolds in MAP kinase signalling. Cellular signalling 2009, 21:462-469.

205. Brennan DF, Dar AC, Hertz NT, Chao WCH, Burlingame AL, Shokat KM, Barford D: A Raf-induced allosteric transition of KSR stimulates phosphorylation of MEK. Nature 2011, 1-6.

206. Monetti M, Nagaraj N, Sharma K, Mann M: Large-scale phosphosite quantification in tissues by a spike-in SILAC method. Nat Methods 2011, 8:655-658.

207. Oppermann FS, Gnad F, Olsen JV, Hornberger R, Greff Z, Keri G, Mann M, Daub H: Large-scale proteomics analysis of the human kinome. Mol Cell Proteomics 2009, 8:1751-1764. 
208. Tan CS, Pasculescu A, Lim WA, Pawson T, Bader GD, Linding R: Positive selection of tyrosine loss in metazoan evolution. Science 2009, 325:1686-1688.

209. Moran MF, Koch CA, Anderson D, Ellis C, England L, Martin GS, Pawson T: Src homology region 2 domains direct protein-protein interactions in signal transduction. Proceedings of the National Academy of Sciences of the United States of America 1990, 87:8622-8626.

210. Koch CA, Anderson D, Moran MF, Ellis C, Pawson T: SH2 and SH3 domains: elements that control interactions of cytoplasmic signaling proteins. Science 1991, 252:668-674.

211. Won AP, Garbarino JE, Lim WA: Recruitment interactions can override catalytic interactions in determining the functional identity of a protein kinase. Proceedings of the National Academy of Sciences of the United States of America 2011, 108:9809-9814.

212. Pawson T, Kofler M: Kinome signaling through regulated protein-protein interactions in normal and cancer cells. Current opinion in cell biology 2009, 21:147-153.

213. Nagakura I, Ormond J, Sossin WS: Mechanisms regulating ApTrkl, a Trklike receptor in Aplysia sensory neurons. Journal of neuroscience research 2008, 86:2876-2883.

214. Boucher J, Macotela Y, Bezy O, Mori MA, Kriauciunas K, Kahn CR: A kinaseindependent role for unoccupied insulin and IGF-1 receptors in the control of apoptosis. Sci Signal 2010, 3:ra87.

215. Zhang M, Riedel $\mathrm{H}$ : Insulin receptor kinase-independent signaling via tyrosine phosphorylation of phosphatase PHLPP1. J Cell Biochem 2009, 107:65-75

216. Taddei ML, Parri M, Angelucci A, Onnis B, Bianchini F, Giannoni E, Raugei G, Calorini L, Rucci N, Teti A, et al: Kinase-dependent and -independent roles of EphA2 in the regulation of prostate cancer invasion and metastasis. Am J Pathol 2009, 174:1492-1503.

217. Kullander K, Mather NK, Diella F, Dottori M, Boyd AW, Klein R: Kinasedependent and kinase-independent functions of EphA4 receptors in major axon tract formation in vivo. Neuron 2001, 29:73-84.

218. Gu C, Park S: The EphA8 receptor regulates integrin activity through p110gamma phosphatidylinositol-3 kinase in a tyrosine kinase activityindependent manner. Mol Cell Biol 2001, 21:4579-4597.

219. Birgbauer E, Cowan CA, Sretavan DW, Henkemeyer M: Kinase independent function of EphB receptors in retinal axon pathfinding to the optic disc from dorsal but not ventral retina. Development 2000, 127:1231-1241.

220. Grunwald IC, Korte M, Wolfer D, Wilkinson GA, Unsicker K, Lipp HP, Bonhoeffer T, Klein R: Kinase-independent requirement of EphB2 receptors in hippocampal synaptic plasticity. Neuron 2001, 32:1027-1040.

221. Genander M, Halford MM, Xu NJ, Eriksson M, Yu Z, Qiu Z, Martling A, Greicius G, Thakar S, Catchpole T, et al: Dissociation of EphB2 signaling pathways mediating progenitor cell proliferation and tumor suppression. Cell 2009, 139:679-692.

222. Ji XD, Li G, Feng YX, Zhao JS, Li JJ, Sun ZJ, Shi S, Deng YZ, Xu JF, Zhu YQ, et al: EphB3 is overexpressed in non-small-cell lung cancer and promotes tumor metastasis by enhancing cell survival and migration. Cancer Res 2011, 71:1156-1166.

223. Miao H, Strebhardt K, Pasquale EB, Shen TL, Guan JL, Wang B: Inhibition of integrin-mediated cell adhesion but not directional cell migration requires catalytic activity of EphB3 receptor tyrosine kinase. Role of Rho family small GTPases. J Biol Chem 2005, 280:923-932.

224. Wimmer-Kleikamp SH, Janes PW, Squire A, Bastiaens PI, Lackmann M: Recruitment of Eph receptors into signaling clusters does not require ephrin contact. The Journal of cell biology 2004, 164:661-666.

225. Himanen JP, Yermekbayeva L, Janes PW, Walker JR, Xu K, Atapattu L, Rajashankar KR, Mensinga A, Lackmann M, Nikolov DB, Dhe-Paganon S: Architecture of Eph receptor clusters. Proceedings of the National Academy of Sciences of the United States of America 2010, 107:10860-10865.

226. Chin-Sang ID, George SE, Ding M, Moseley SL, Lynch AS, Chisholm AD: The ephrin $\mathrm{VAB}-2 / \mathrm{EFN}-1$ functions in neuronal signaling to regulate epidermal morphogenesis in C. elegans. Cell 1999, 99:781-790.

227. George SE, Simokat K, Hardin J, Chisholm AD: The VAB-1 Eph receptor tyrosine kinase functions in neural and epithelial morphogenesis in $C$. elegans. Cell 1998, 92:633-643.

228. Wang X, Roy PJ, Holland SJ, Zhang LW, Culotti JG, Pawson T: Multiple ephrins control cell organization in $C$. elegans using kinase-dependent and -independent functions of the VAB-1 Eph receptor. Mol Cell 1999, 4:903-913.
229. Lennartsson J, Shivakrupa R, Linnekin D: Synergistic growth of stem cell factor and granulocyte macrophage colony-stimulating factor involves kinase-dependent and -independent contributions from c-Kit. J Biol Chem 2004, 279:44544-44553.

230. Lin J, Tao J, Dyer RB, Herzog NK, Justement LB: Kinase-independent potentiation of $B$ cell antigen receptor-mediated signal transduction by the protein tyrosine kinase Src. J Immunol 1997, 159:4823-4833.

231. Harvey AJ, Crompton MR: Use of RNA interference to validate Brk as a novel therapeutic target in breast cancer: Brk promotes breast carcinoma cell proliferation. Oncogene 2003, 22:5006-5010.

232. Putzke AP, Hikita ST, Clegg DO, Rothman JH: Essential kinase-independent role of a Fer-like non-receptor tyrosine kinase in Caenorhabditis elegans morphogenesis. Development 2005, 132:3185-3195.

233. Warmuth M: The Src Family Kinase Hck Interacts with Bcr-Abl by a Kinase-independent Mechanism and Phosphorylates the Grb2-binding Site of Bcr. Journal of Biological Chemistry 1997, 272:33260-33270.

234. Ren X, Cao C, Zhu L, Yoshida K, Kharbanda S, Weichselbaum R, Kufe D: Lyn tyrosine kinase inhibits nuclear export of the p53 tumor suppressor. Cancer Biol Ther 2002, 1:703-708.

235. Nie Y, Li HH, Bula CM, Liu X: Stimulation of p53 DNA binding by c-Abl requires the p53 C terminus and tetramerization. Mol Cell Biol 2000, 20:741-748.

236. Chen X, Zhang J, Lee J, Lin PS, Ford JM, Zheng N, Zhou P: A kinaseindependent function of c-Abl in promoting proteolytic destruction of damaged DNA binding proteins. Molecular cell 2006, 22:489-499.

237. Henkemeyer M, West SR, Gertler FB, Hoffmann FM: A novel tyrosine kinase-independent function of Drosophila abl correlates with proper subcellular localization. Cell 1990, 63:949-960.

238. Li J, Rix U, Fang B, Bai Y, Edwards A, Colinge J, Bennett KL, Gao J, Song L, Eschrich S, et al: A chemical and phosphoproteomic characterization of dasatinib action in lung cancer. Nat Chem Biol 2010, 6:291-299.

239. Yang W, Lin Q, Zhao J, Guan JL, Cerione RA: The nonreceptor tyrosine kinase ACK2, a specific target for $\mathrm{Cdc} 42$ and a negative regulator of cell growth and focal adhesion complexes. J Biol Chem 2001, 276:43987-43993.

240. Gottar-Guillier M, Dodeller F, Huesken D, lourgenko V, Mickanin C, Labow M, Gaveriaux S, Kinzel B, Mueller M, Alitalo K, et al: The tyrosine kinase $\mathrm{BMX}$ is an essential mediator of inflammatory arthritis in a kinase-independent manner. J Immunol 2011, 186:6014-6023.

241. Hao S, Qi Q, Hu J, August A: A kinase independent function for Tec kinase ITK in regulating antigen receptor induced serum response factor activation. FEBS Lett 2006, 580:2691-2697.

242. Dombroski D, Houghtling RA, Labno CM, Precht P, Takesono A, Caplen NJ, Billadeau DD, Wange RL, Burkhardt JK, Schwartzberg PL: Kinaseindependent functions for Itk in TCR-induced regulation of Vav and the actin cytoskeleton. J Immunol 2005, 174:1385-1392.

243. Au-Yeung BB, Levin SE, Zhang C, Hsu LY, Cheng DA, Killeen N, Shokat KM, Weiss A: A genetically selective inhibitor demonstrates a function for the kinase Zap70 in regulatory T cells independent of its catalytic activity. Nat Immunol 2010, 11:1085-1092.

244. Sorrentino A, Thakur N, Grimsby S, Marcusson A, von Bulow V, Schuster N, Zhang S, Heldin CH, Landstrom M: The type I TGF-beta receptor engages TRAF6 to activate TAK1 in a receptor kinase-independent manner. Nat Cell Biol 2008, 10:1199-1207.

245. Romano D, Matallanas D, Weitsman G, Preisinger C, Ng T, Kolch W: Proapoptotic Kinase MST2 Coordinates Signaling Crosstalk between RASSF1A, Raf-1, and Akt. Cancer Res 2010.

246. Alavi AS, Acevedo L, Min W, Cheresh DA: Chemoresistance of endothelial cells induced by basic fibroblast growth factor depends on Raf-1mediated inhibition of the proapoptotic kinase, ASK1. Cancer research 2007, 67:2766-2772.

247. Moran ST, Haider K, OW Y, Milton P, Chen L, Pillai S: Protein kinase Cassociated kinase can activate NFkappaB in both a kinase-dependent and a kinase-independent manner. J Biol Chem 2003, 278:21526-21533.

248. Schumacher S, Laass K, Kant S, Shi Y, Visel A, Gruber AD, Kotlyarov A, Gaestel M: Scaffolding by ERK3 regulates MK5 in development. The EMBO Journal 2004, 23:4770-4779.

249. Kim KY, Levin DE: Mpk1 MAPK association with the Paf1 complex blocks Sen1-mediated premature transcription termination. Cell 2011, 144:745-756.

250. Saelzler MP, Spackman CC, Liu Y, Martinez LC, Harris JP, Abe MK: ERK8 down-regulates transactivation of the glucocorticoid receptor through Hic-5. J Biol Chem 2006, 281:16821-16832. 
251. Hayashi S, Yamaguchi M: Kinase-independent activity of Cdc2/cyclin A prevents the S phase in the Drosophila cell cycle. Genes Cells 1999, 4:111-122.

252. Yu VP, Baskerville C, Grunenfelder B, Reed SI: A kinase-independent function of Cks1 and Cdk1 in regulation of transcription. Mol Cell 2005, 17:145-151.

253. Zhang J, Herrup K: Cdk5 and the non-catalytic arrest of the neuronal cell cycle. Cell Cycle 2008, 7:3487-3490.

254. Klein TJ, Jenny A, Djiane A, Mlodzik M: CKlepsilon/discs overgrown promotes both Wnt-Fz/beta-catenin and Fz/PCP signaling in Drosophila. Curr Biol 2006, 16:1337-1343.

255. Kang TH, Kim KT: Negative regulation of ERK activity by VRK3-mediated activation of VHR phosphatase. Nature cell biology 2006, 8:863-869.

256. Bronner M, Hertz R, Bar-Tana J: Kinase-independent transcriptional coactivation of peroxisome proliferator-activated receptor alpha by AMPactivated protein kinase. Biochem J 2004, 384:295-305.

257. Sapir T, Sapoznik S, Levy T, Finkelshtein D, Shmueli A, Timm T, Mandelkow EM, Reiner O: Accurate balance of the polarity kinase MARK2/ Par-1 is required for proper cortical neuronal migration. J Neurosci 2008 , 28:5710-5720

258. Mor I, Carlessi R, Ast T, Feinstein E, Kimchi A: Death-associated protein kinase increases glycolytic rate through binding and activation of pyruvate kinase. Oncogene 2011.

259. Shishido T, Woo CH, Ding B, McClain C, Molina CA, Yan C, Yang J, Abe J: Effects of MEK5/ERK5 association on small ubiquitin-related modification of ERK5: implications for diabetic ventricular dysfunction after myocardial infarction. Circulation research 2008, 102:1416-1425.

260. Lu Z, Xu S, Joazeiro C, Cobb MH, Hunter T: The PHD domain of MEKK1 acts as an E3 ubiquitin ligase and mediates ubiquitination and degradation of ERK1/2. Molecular cell 2002, 9:945-956.

261. Gnesutta N, Qu J, Minden A: The serine/threonine kinase PAK4 prevents caspase activation and protects cells from apoptosis. J Biol Chem 2001, 276:14414-14419.

262. Cinar B, Collak FK, Lopez D, Akgul S, Mukhopadhyay NK, Kilicarslan M, Gioeli DG, Freeman MR: MST1 Is a Multifunctional Caspase-Independent Inhibitor of Androgenic Signaling. Cancer research 2011, 71:4303-4313.

263. Chen Y, Li S, Tong C, Zhao Y, Wang B, Liu Y, Jia J, Jiang J: G proteincoupled receptor kinase 2 promotes high-level Hedgehog signaling by regulating the active state of Smo through kinase-dependent and kinase-independent mechanisms in Drosophila. Genes \& development 2010, 24:2054-2067.

264. Jiang $X$, Yang $P, M a ~ L:$ Kinase activity-independent regulation of cyclin pathway by GRK2 is essential for zebrafish early development. Proceedings of the National Academy of Sciences of the United States of America 2009, 106:10183-10188

265. Jorgensen R, Holliday ND, Hansen JL, Vrecl M, Heding A, Schwartz TW, Elling CE: Characterization of G-protein coupled receptor kinase interaction with the neurokinin-1 receptor using bioluminescence resonance energy transfer. Molecular pharmacology 2008, 73:349-358.

266. Fernandez N, Gottardo FL, Alonso MN, Monczor F, Shayo C, Davio C: Roles of phosphorylation dependent and independent mechanisms in the regulation of Histamine $\mathrm{H} 2$ receptor by $\mathrm{G}$ Protein-coupled Receptor Kinase 2. J Biol Chem 2011.

267. Kang Jl, Ahn BY: HCV-induced PKR activation is stimulated by the mitogen- and stress-activated protein kinase MSK2. Biochemical and biophysical research communications 2011, 407:248-253.

268. Ge Y, Wu AL, Warnes C, Liu J, Zhang C, Kawasome H, Terada N, Boppart MD, Schoenherr CJ, Chen J: mTOR regulates skeletal muscle regeneration in vivo through kinase-dependent and kinase-independent mechanisms. Am J Physiol Cell Physiol 2009, 297:C1434-1444.

269. Subramanian L, Nakamura TM: A kinase-independent role for the Rad3 (ATR)-Rad26(ATRIP) complex in recruitment of Tel1(ATM) to telomeres in fission yeast. PLOS Genet 2010, 6:e1000839.

270. Ma Y, Greider CW: Kinase-independent functions of TEL1 in telomere maintenance. Mol Cell Biol 2009, 29:5193-5202

271. Hase M, Depre C, Vatner SF, Sadoshima J: H11 has dose-dependent and dual hypertrophic and proapoptotic functions in cardiac myocytes. The Biochemical journal 2005, 388:475-483.

272. Huang CL, Yang SS, Lin SH: Mechanism of regulation of renal ion transport by WNK kinases. Current opinion in nephrology and hypertension 2008, 17:519-525.
273. Hong C, Moorefield KS, Jun P, Aldape KD, Kharbanda S, Phillips HS, Costello JF: Epigenome scans and cancer genome sequencing converge on WNK2, a kinase-independent suppressor of cell growth. Proc Natl Acad Sci USA 2007, 104:10974-10979.

274. Lange A, Wickstrom SA, Jakobson M, Zent R, Sainio K, Fassler R: Integrinlinked kinase is an adaptor with essential functions during mouse development. Nature 2009, 461:1002-1006.

275. Mackinnon AC, Qadota H, Norman KR, Moerman DG, Williams BD: C. elegans PAT-4/LK functions as an adaptor protein within integrin adhesion complexes. Curr Biol 2002, 12:787-797.

276. Zervas CG, Gregory SL, Brown NH: Drosophila integrin-linked kinase is required at sites of integrin adhesion to link the cytoskeleton to the plasma membrane. J Cell Biol 2001, 152:1007-1018.

277. Grashoff C, Aszodi A, Sakai T, Hunziker EB, Fassler R: Integrin-linked kinase regulates chondrocyte shape and proliferation. EMBO Rep 2003, 4:432-438.

278. Sakai T, Li S, Docheva D, Grashoff C, Sakai K, Kostka G, Braun A, Pfeifer A, Yurchenco PD, Fassler R: Integrin-linked kinase (ILK) is required for polarizing the epiblast, cell adhesion, and controlling actin accumulation. Genes Dev 2003, 17:926-940.

279. Lorenz K, Grashoff C, Torka R, Sakai T, Langbein L, Bloch W, Aumailley M, Fassler R: Integrin-linked kinase is required for epidermal and hair follicle morphogenesis. J Cell Biol 2007, 177:501-513.

280. Hu Y, Baud V, Oga T, Kim Kl, Yoshida K, Karin M: IKKalpha controls formation of the epidermis independently of NF-kappaB. Nature 2001, 410:710-714.

281. Ashida N, Senbaneriee S, Kodama S, Foo SY, Coggins M, Spencer JA, Zamiri P, Shen D, Li L, Sciuto T, et al: IKKbeta regulates essential functions of the vascular endothelium through kinase-dependent and -independent pathways. Nat Commun 2011, 2:318.

282. Toya $M$, Terasawa $M$, Nagata $K$, lida $Y$, Sugimoto A: A kinase-independent role for Aurora A in the assembly of mitotic spindle microtubules in Caenorhabditis elegans embryos. Nature cell biology 2011, 13:710-716.

283. Riefler GM, Dent SY, Schumacher JM: Tousled-mediated activation of Aurora B kinase does not require Tousled kinase activity in vivo. $J$ Biol Chem 2008, 283:12763-12768.

284. Mahjoub MR, Qasim Rasi M, Quarmby LM: A NIMA-related kinase, Fa2p, localizes to a novel site in the proximal cilia of Chlamydomonas and mouse kidney cells. Mol Biol Cell 2004, 15:5172-5186.

285. Twomey C, Wattam SL, Pillai MR, Rapley J, Baxter JE, Fry AM: Nek2B stimulates zygotic centrosome assembly in Xenopus laevis in a kinaseindependent manner. Dev Biol 2004, 265:384-398.

286. Abeliovich H, Zhang C, Dunn WA, Shokat KM, Klionsky DJ: Chemical genetic analysis of Apg1 reveals a non-kinase role in the induction of autophagy. Molecular biology of the cell 2003, 14:477-490.

287. Schoenwaelder SM, Ono A, Sturgeon S, Chan SM, Mangin P, Maxwell MJ, Turnbull S, Mulchandani M, Anderson K, Kauffenstein G, et al: Identification of a unique co-operative phosphoinositide 3-kinase signaling mechanism regulating integrin alpha llb beta 3 adhesive function in platelets. J Biol Chem 2007, 282:28648-28658.

288. Ueki K, Fruman DA, Yballe CM, Fasshauer M, Klein J, Asano T, Cantley LC, Kahn CR: Positive and negative roles of p85 alpha and p85 beta regulatory subunits of phosphoinositide 3-kinase in insulin signaling. J Biol Chem 2003, 278:48453-48466.

289. Chamberlain MD, Chan T, Oberg JC, Hawrysh AD, James KM, Saxena A, Xiang J, Anderson DH: Disrupted RabGAP function of the $p 85$ subunit of phosphatidylinositol 3-kinase results in cell transformation. J Biol Chem 2008, 283:15861-15868.

290. Garcia Z, Silio V, Marques M, Cortes I, Kumar A, Hernandez C, Checa Al, Serrano A, Carrera AC: A PI3K activity-independent function of p85 regulatory subunit in control of mammalian cytokinesis. EMBO J 2006 , 25:4740-4751.

291. Windhorst S, Blechner C, Lin HY, Elling C, Nalaskowski M, Kirchberger T, Guse AH, Mayr GW: Ins $(1,4,5)$ P3 3-kinase-A overexpression induces cytoskeletal reorganization via a kinase-independent mechanism. Biochem J 2008, 414:407-417.

doi:10.1186/1478-811X-9-23

Cite this article as: Rauch et al.: The secret life of kinases: functions beyond catalysis. Cell Communication and Signaling 2011 9:23. 